JUNE 1990

REPORT OF THE CIRRPC EXECUTTVE

COMMITTEE REGARDING EPA NESHAP

REGULATIONS ON RADIONUCLIDES

FOR MEDICAL RESEARCH INSTITUTIONS

AND RADIOPHARMACEUTICAL

MANUFACTURERS

Committee on Interagency Radiation

Research and Policy Coordination

Office of Science and Technology Policy Executive Office of the President

Washington, D.C. 20506

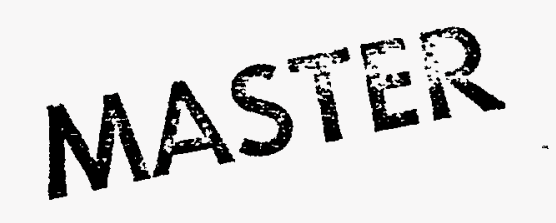


COMMITTEE ON INTERAGENCY RADIATION RESEARCH

AND POLICY COORDINATION

1019 Nineteenth Street, NW, Suite 700

Washington, D.C. 20036

June 26,1990

James B. Wyngaarden, M.D.

Associated Director for Iife sciences

office of Science and Technology Policy

Executive office of the President

Washington, D.C. 20508

Dear Dr. Wyngaarden:

In response to your request of May 16, 1990, the CIRRPC Executive committee has reviewed the arguments presented by the American College of Nuclear Physicians and the society of Nuclear Medicine regarding National Emission Standards for Radionuclide Emissions From Facilities Iicensed by the Nuclear Regulatory Commission and Federal Facilities Not covered by Subpart H. A copy of the report of the Executive committee is enciosed.

The report concludes that application of the standards would impose significant financial and administrative burdens with no concomitant reduction in risk.

If we can be of any further assistance, please let me know.

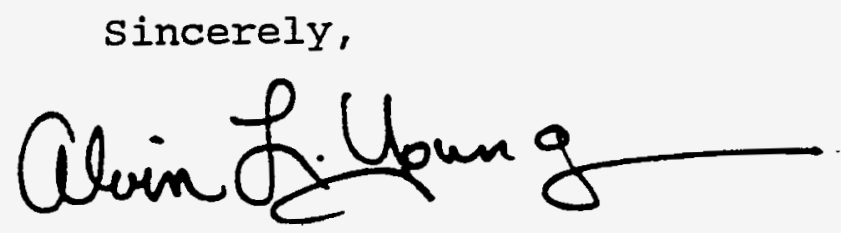

\author{
Alvin I. Young \\ Chairman
}

Enclosure: as stated

DISCLAIMER

ALY/CdI

This report was prepared as an account of work sponsored by an agency of the United States Government. Neither the United States Government nor any agency thereof, nor any of their employees, makes any warranty, express or implied, or assumes any legal liability or responsibility for the accuracy, completeness, or usefulness of any information, apparatus, product, or process disclosed, or represents that its use would not infringe privately owned rights. Reference herein to any specific commercial product, process, or service by trade name, trademark, manufacturer, or otherwise does not necessarily constitute or imply its endorsement, recommendation, or favoring by the United States Government or any agency thereof. The views and opinions of authors expressed herein do not necessarily state or reflect those of the United States Government or any agency thereof. 
AND POLICY COORDINATION

1019 Nineteenth Street, NW, Suite 700

Washington, D.C. 20036

June 26,1990

Dr. Alvin Young

Chairman, CIRRPC

101919 th street, N.W., Suite 700

Washington, D.C. 20036

Dear Dr. Young:

In response to your request of May 22, 1990, the enclosed Report of the CIRRPC Executive committee Regarding EPA NESHAP Regulations on Radionuclide Emissions from NRC-Licensed Medical and Medical Research Institutions and Radiopharmaceutical Manufacturers has been prepared for the CIRRPC Executive Committee. The report concludes that application of the standards would impose significant financial and administrative burdens with no concomitant reduction in risk.

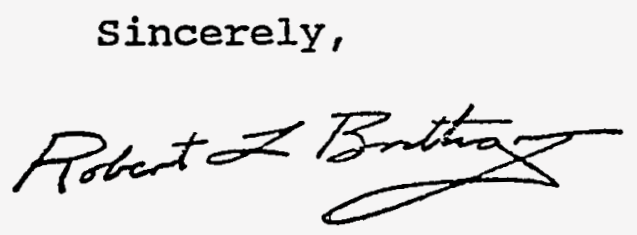

Robert L. Brittigan Executive Secretary

Enclosure: as stated

$\mathrm{RIB} / \mathrm{CdI}$ 
COMMITTEE ON INTERAGENCY RADIATION RESEARCH

AND POLICY COORDINATION

1019 Nineteenth Street, NW, Suite 700

Washington, D.C. 20036

June 26, 1990

\section{REPORT OF THE CIRRPC EXECUTIVE COMMITTEE REGARDING EPA NESHAP REGULATIONS ON RADIONUCLIDE EMISSIONS FROM NRC-LICENSED MEDICAL AND MEDICAL RESEARCH INSTITUTIONS AND RADIOPHARMACEUTICAL MANUFACTURERS}

\section{A. INTRODUCTION}

On May 16, 1990 Dr. James Wyngaarden, Associate Director for Life Sciences, Office of Science and Technology Policy (OSTP) met with representatives of the American College of Nuclear Physicians (ACNP) and the Society for Nuclear Medicine (SNM) to discuss the Environmental Protection Agency's (EPA) proposed National Emission Standards for Hazardous Air Pollutants (NESHAPs); Radionuclides. The ACNP's and SNM's main concern was that the Nuclear Regulatory Commission's (NRC) current regulation of nuclear medicine activities is adequate and the EPA standards would only institute dual regulation over activities where there is no demonstrated public health hazard to warrant additional regulation. Facilities engaged in these activities are hospitals, biomedical research facilities, and radiopharmaceutical manufacturing and processing facilities. These standards for NRC-licensed facilities are currently stayed until July 12, 1990 by EPA for reasons of reconsideration with respect to issues of duplicative regulation and possible effects on medical treatment.

Following this meeting, Dr. Wyngaarden requested of Dr. Alvin L. Young the assistance of the Executive Committee of the Committee on Interagency Radiation Research and Policy Coordination (CIRRPC) in determining the validity of the comments submitted by ACNP and SNM to EPA (Appendix 1). These comments were submitted to EPA in response to publication of the final rules on emission standards in the Federal Register on December 15, 1989. A summary of the relevant portion of EPA's regulation is provided as Appendix 2.

In response to Dr. Wyngaarden's request, the CIRRPC Executive Committee attempted to assemble and review available information relative to the comments submitted by ACNP and SNM. On May 24, 1990, three members of the Executive Committee (Mr. Robert Brittigan and Drs. Randall Caswell and Percival McCormack) held a meeting to solicit input from the National Institutes of Health (NIH) and the NRC. See Appendices 3 and 4 for NIH and NRC comments, respectively. These materials were reviewed in the development of this report. 
The material presented in the following sections of this report is limited to that directly applicable to the ACNP and SNM's comments and is not intended to cover the entire scope of either the regulations or the comments received. Section $B$ identifies the major issues and discusses the assembled information in support of these issues, Section C gives the status of regulatory and Congressional actions, and Section D presents the Executive Committee's conclusions on the validity of the ACNP and SNM's arguments supportive to their objective of exemption of nuclear medicine activities from dual regulation.

\section{B. ISSUES OF CONCERN}

\section{Issue 1: Dual Regulation}

Under the current regulatory scheme, nuclear medicine facilities, medical research facilities and radiopharmaceutical manufacturers are regulated by the NRC under the provisions of the Atomic Energy Act (AEA). The primary regulations for the control of radionuclide emissions from medically-oriented uses are contained in NRC's 10 CFR 20, Standards for Protection Against Radiation, and 10 CFR 35, Medical Uses of Byproduct Material. In order to satisfy the AEA mandate to establish standards which protect public health and safety, the NRC regulations prescribe limits for occupational exposures to radiation, permissible concentrations of radioactive materials in the workplace, concentrations of radioactive materials which may be discharged into effluents from nuclear facilities, and limits on levels of exposure to members of the general public. In addition to satisfying these requirements, NRC licensees are "to make every reasonable effort to maintain radiation exposures, and releases of radioactive materials in effluents to unrestricted areas as low as reasonably achievable" (ALARA). The result of such controls has been a system which can be considered to have provided adequate protection of public health with an ample margin of safety. Compliance with the NRC regulations is primarily demonstrated through reporting and recordkeeping requirements of both monitoring (e.g., personnel monitoring) and measuring (e.g., concentrations of radioactive materials in air, in the body or in excreta) results.

If EPA's NESHAP regulations become final on July 12, 1990, the licensees of the NRC, including the nuclear medical communities, will be subject to dual regulation under section 112 of the Clean Air Act. While release of the same radioactive material from the production and use of radiopharmaceuticals and radiolabeled compounds in research will be subject to both sets of regulations, the limits and methods of demonstrating compliance are not the same. The NRC regulations define releases on an activity per volume basis, whereas, the NESHAPs will control emissions according to the annual exposure to members of the public. Furthermore, rather than the direct monitoring and measuring required by $10 \mathrm{CFR}$ 20, compliance with the NESHAPs regulations will be demonstrated by limiting annual possession quantities or concentration levels or using EPA's COMPLY computer code. This COMPLY code requires a considerable number of data points, such as stack/vent parameters, for each release point at a facility. 
A review of the relevant information indicated that this dual regulation of the same radionuclide emissions will be costly both in terms of time and money (see Issue 3) and will result in no clearly demonstrated increased protection of the public (see Issue 2). This concern was expressed by EPA in several Federal Register notices on this regulation. In October 1984, EPA stated that with respect to NRC-licensed facilities, the record "does not support the conclusion that regulation of (these)...facilities is necessary to protect public health with an ample margin of safety (49 FR 43912). Later, EPA stated that "it continues to believe existing emissions from these sources are already so low that the public health is already protected with an ample margin of safety". Recently, a November 15, 1989 letter to the Honorable Quentin Burdick from EPA and the NIH noted that the proposed regulatory scheme involved unnecessary duplication which could divert resources from needed research and programs (Appendix 5). The letter noted that NRC and the DOE shared these concerns and that the agencies believed that "the pending revisions to the Clean Air Act should contain a provision to eliminate the unnecessary duplication to regulate emissions from NRC-licensed facilities". In recognition of these concerns, along with the final rule, EPA published a Notice of Reconsideration for regulations covering the NRC-licensee category.

\section{Issue 2: Protection of Public Health}

The ACNP and the SNM contend that removing the EPA's regulation of nuclear medicine and radiopharmaceuticals would not "endanger public health", the basic criteria for regulating under Section 112(a) of the Clean Air Act (letter to EPA, dated February 9, 1990, Appendix 1); a position strongly supported by the NIH (letter to EPA, dated February 9, 1990, Appendix 3). EPA indirectly acknowledges this no loss in public health protection by stating as its objective that it "...has decided to continue regulation of this category to insure that the current levels of emissions are not increased" (Federal Register 54:51654-51714, 12/15/89).

NIH believes that imposition of the EPA regulation "on NRC medical and research licensees is not only unwarranted but could have a negative effect on the treatment and survival of some patients ... an increase in mortality for both hyperthyroidism and thyroid carcinoma." Compliance with EPA possession limits may, in some hospitals and clinics, restrict the number of diagnostic and/or therapeutic applications of radiopharmaceuticals and, thus, deny some patients important medical services. NIH concludes that, "... if even a single hyperthyroid or thyroid cancer patient is affected by the implementation of this standard, the benefit/risk balance is negative." ACNP and SNM point out that "there is no chemotherapy substitute for I-131 in the treatment of thyroid cancer" and that while nonradioactive drugs can be used in the treatment of hyperthyroidism, these have side effects which prevent their use on a permanent basis. They state that "I-131 cures hyperthyroidism and its availability must continue for effective patient care." [NOTE: The radionuclides of major concern in addressing this issue are certain isotopes of iodine, although other radionuclides, such as technetium $99 \mathrm{~m}$, xenon-133, carbon-14, and tritium, are controlled under NRC regulations and would be also controlled under EPA's NESHAPs if EPA's rule becomes effective.] 
Further, NIH points out that not only is the EPA standard of 10 mrem/yr "inherently conservative" but that every factor that affects the calculations of compliance with this standard is a conservative choice. EPA estimates that current release from these facilities licensed under NRC's regulations for operations and protection of workers and members of the general public, with one exception, result in individual risks that are "quite low" with doses less than $1 \mathrm{mrem} / \mathrm{yr}$ to the "nearby resident". The exception is a radiopharmaceutical manufacturer for which EPA states only that the annual dose to a nearby resident is greater than 1 mrem/yx. [EPA 520/1-89-007, Vol 3] EPA further estimates that the total number of fatal cancers attributable to all calculated emissions from 3680 licensed hospitals is 0.06 case per year, and that from 120 licensed radiopharmaceutical manufacturers 0.02 case per year. Their estimate of non-fatal cancers, mostly thyroid cancer attributable to radioactive iodine releases, is 0.8 case per year.

Thus, there appears to be general agreement that withdrawing EPA's regulations for this category of sources would not endanger public health and NRC's regulations ensure adequate protection.

\section{Issue 3: Economic Impacts}

No detailed economic assessment of potential impacts of implementing 40 CFR 91 on hospitals and radiopharmaceutical manufacturers has been performed by EPA. In its background information document (Vol. 3) it recognized that over half of the hospitals in the U.S. handle radiopharmaceuticals and that more than 100 firms are involved in the manufacturing, preparation, and packaging of radiopharmaceuticals. According to the Oak Ridge National Laboratory, the production of such products constitutes a $\$ 250$ million-a-year industry with as many as 40,000 medical procedures a day in U.S. hospitals and clinics (Inside NRC, June $6,1990)$. Seventy to eighty percent of all research at NIH is reported to require radioactive materials.

EPA reports that no supplementary emission controls for radioactivity were warranted for these facilities, except for one radiopharmaceutical manufacturer. For this facility EPA estimates increased control costs of $\$ 350,000$ for an "associated" risk reduction from 0.008 to 0.003 cancer death per year. No assessment of impacts on patient treatment or viability of the associated industry was made.

Two major areas of economic impacts are likely to result from promulgation of the EPA regulation: a substantial monetary burden on nuclear medicine facilities to demonstrate compliance with EPA regulations; and a potential for loss in U.S. manufacturing of radiopharmaceuticals, which in turn could affect not only patient care per se but also the cost of that care. Cost of compliance would be passed to patients and consumers. 
The ACNP and SNM estimate the following compliance costs for more than 3900 NRC-licensed hospitals:

$$
\begin{aligned}
& 600 \text { hospitals ( }>500 \text { beds), } \\
& 3,300 \text { hospitals ( }<500 \text { beds), }
\end{aligned}
$$$$
\begin{array}{r}
\text { \$35K/hospital---\$21M/yr } \\
\text { \$5K/hospital-- } \$ 16 \mathrm{M} / \mathrm{yr} \\
\text { TOTAL---\$37M/yr }
\end{array}
$$

They also estimate that costs of radiopharmaceuticals could be increased by $20 \%$, resulting in cost passed on to users (hospitals, etc.) of $\$ 6 \mathrm{M} / \mathrm{yr}$ for this industry.

According to ACNP/SNM, Duke University has estimated that it would cost $\$ 500 \mathrm{~K}$ to comply with the EPA regulation and the NIH has estimated similar costs. Overall, the ACNP/SNM estimate a $\$ 100 \mathrm{M}$ annual cost to the nuclear medicine industry, not including any costs associated with radionuclides used in research and in radioimmunoassays.

Indications are that the availability of radiolabeled compounds for biomedical research from a U.S. supplier would cease because of the additional regulatory requirements. Likewise, an already greatly reduced U.S. radiopharmaceutical industry would be further reduced with greater dependence on foreign suppliers such as France, Canada, and the United Kingdom. This reduction in availability would be counter to the recommendations of a 1989 Department of Energy report that strongly supports an effort to revitalize the U.S. production of radioactive materials that are vital to continued related biomedical research and to advancements in nuclear medicine. Overall, EPA's regulations would appear certain to increase health care costs and have negative consequences on current and future practices of nuclear medicine in the treatment and diagnosis of disease.

\section{STATUS OF REGULATIONS AND CONGRESSIONAL ACTIONS}

\section{Status of Regulations}

The EPA is currently facing legal and administrative challenges to its NESHAPs rulemaking published in December 1989 (Inside EPA, June 15, 1990). Eleven petitions, representing a range from industrial to environmental viewpoints, have been consolidated into one by the courts. Since pending complaints all deal with generic issues regarding the rulemaking, rather than with specific standards set by NESHAPS, EPA is considering whether to voluntarily suspend the rules or defend them in court. EPA is bound by law to honor all petitions and, therefore, may choose to suspend the rulemaking while it reconsiders the challenged issues. Meanwhile, EPA's 120 day current suspension of Subsection I for NRC licensees ends on July 12, 1990. 


\section{Congressional Actions}

The 101st Congress is currently considering legislation to amend the Clean Air Act. One issue being looked at is dual regulation by EPA and by NRC of radionuclides regulated under the Atomic Energy Act. The Senate Environmental and Public Works Committee adopted an amendment that excluded radionuclide emissions from NRC-licensed facilities from the Clean Air Act's definition of air pollutant. On April 3, 1990, the Senate passed S.1630 with an amendment offered by Senator Alan Simpson which provides, in part, that, "[N]o standard for radionuclide emissions from facilities licensed by the Nuclear Regulatory Commission (or an Agreement State) is required to be promulgated...if the Administrator (of EPA) determines...that the regulatory program established by the [NRC] pursuant to the Atomic Energy Act provides an ample margin of safety to protect the public health." The House Energy and Commerce Committee did not adopt a similar amendment to avoid dual regulation, and no such amendment was added to H.R.3030 for changes to the Clean Air Act, passed by the House on May 23, 1990.

At the present time, the Senate has approved a list of nine clean air conferees and the House has yet to select its conferees. The conference is expected to start mid-summer, with no predicted date for completion of its work due to the extensive scope and number of issues to be addressed. If the Senate amendment concerning dual regulation is agreed to in conference, it will undoubtedly impact on the regulatory status discussed above.

\section{CONCLUSION}

There appears to be no compelling public health protection reason for EPA's promulgation of NESHAP regulations to control air emissions of radioactive materials from NRC-licensed facilities engaged in activities associated with the practice and development of nuclear medicine. The NRC's existing regulations provide the necessary controls for protection and EPA's regulations would only add burdensome reporting requirements at substantial cost to medical treatment and diagnosis. Availability of nuclear medicine practice could be impacted and advancements through research delayed. 
APPENDIX 1 


\section{EXECUTIVE OFFICE OF THE PRESIDENT \\ OFFICE OF BCIENCE ANO TECHNOLDGY POLCY \\ WASHINGTON. D.C. 20608}

May 16. 1990

Dear

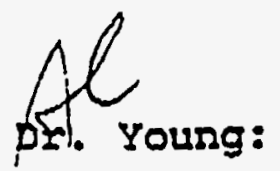

Thls morning I met with three representetiven of the American Callage of Nuclear Physicians (ACNP) to discuss the Environmental Protection Agency'g (EPA) national emissions standards for hazardous air poliutants. Representing the ACNP were DI. Robert E. Hankin, Dr. Carol S. Maroug, and Mg. Valeria A. Fedio. OSTF was represented by myself and Dr. Katherine Yuracko. DI. WiIILam A. $M 11 I B$ and $M r$. Robert $L$. Brittigan attended representing CIRRPC, by InVItation.

The main concers of the ACNP representatives 19 the duplicate regulation of nuclear medical activitias that will bagin epproximately $541 Y$ 12, unless some exemption from EPA regulations can be obtained.

The ACNP representatives argued that current regulation by the Nueloar Regulatory Comnisaion (NRC) 18 wholly adequate, and that there is no pubile nealth hazard that would warrant additional regulation by EPA. DI. Marcus, who 18 both $a$ radioblologtst and a physicten, discussed worst cases of potent1al zisk, 1nvolving for exampie a physician or techniclan administering tharapoutic dogen of radiolodine, and even aljowing for lifetime exposures of maximeliy Ieasonable emounts, calculates thet the cancer incidence 18 well below $10^{-4}$, the EPA sefety 1 imit.

I am onclosing a detalied letter that ACNP has gubmittod to EPA, as comments on the proposed rule. I plan to discuss this letter and the senee of thelI presentation with Jim Maerae, 
Acting Director of the Office of Information and Regulatary Affairs in the office of Menagemant and Budget. It will be very helpful to me to have an opinion of the Executive Committas of CIRRPC as to the validity of the arguments presented in the letter, from the scientific and statistical polnts of view.

If you feel it would be appropriate for CIRRPC to provide. such commentary, I would eppreclate rocelving a reply within about a weak if posalbie.

\section{Sincerely,}<smiles>CC1(C)CCCC1</smiles>

James $B$. Wyngariden, M.D.

Aasociate Director for Lifa sciances

Enejoeure

Dr. AIvin I. Young

Agriculturai Biotachnology office

U.S. Department of Agriculture

Room $321 \mathrm{~A}$ Adminiatration Bullaing

I th and Independence Avenue, S.H.

Harhington, D.C. 20250 


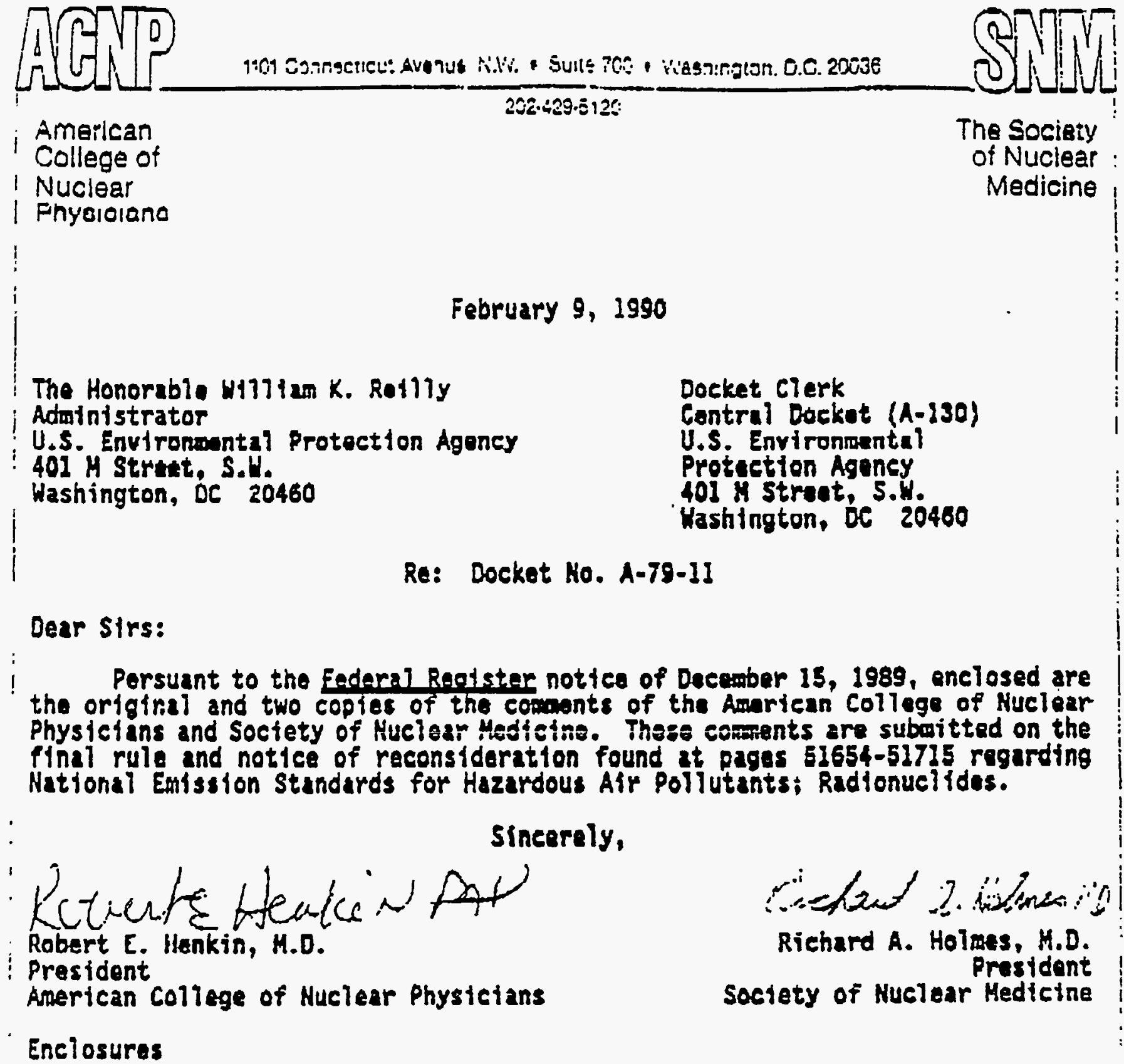




\section{BEFORE THE \\ ENYIROHNENTAL PROTECTION AUENEY \\ WASHINGTON, O.C. \\ FEBRLARY 8, 1980}

In the matter of:

National Eatssion

Standards for Hazardous Air Pollutants; Radionuclides
Docket No.

A-79-11

54 Eed. Bea, 51654

(Decerber 15, 1989)

\section{COWETS OF THE Mistichl COLLEA OF MTCLEAR PHYSICIATS/SOCIETY OF MUGLENR MEOTCRE}

On bohalf of the American Colloge of Nuciear Physicians (ACHP) and the Sociaty of Mucloar Modicino (SNA), which together ruprasunt natriy 12,000 hekith care professtonals and support personnei engaged in the practice of nuclear medicine, W wish to respond to the final rules on entsston standaros for radioactiva hazapdous air polfutants publiched ac a part of 40 CFR 61, soction 113 on Oetober 31, 1989 and the amended appendix $B$ to part 61, published in the Federal Register of Dacanbar 15, 1989 , pR. 51704-15.

Wh11. we supporl, in princtple, the restriction of airborne relecses of radionuclides to the maximum reasonably achloveble extont, the oxposure based targat of 100Rem/y to any individual is overly restrictive for cortain Rey redionuelides. Horeover, the regulations dual lcate areas al raady covered oy the

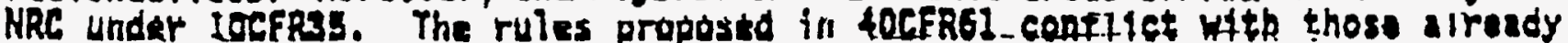
enforced by the KRC. They will be costiy, potent tally hamoer clintcal manegemont of petfants and rasources, and will offor no signifrieant protection to the pubite. Some orovistans may be unenfarceable.

Thus, we strongly recomend reconsideration of the portions of this ruling which pertain to MRC licensoes such as hospitals, nedical and institutional research facilitios, and pharmeautleal/radiopharmaceutical houses.

of the saveral airborne radtonucildes generated by nuclear nediefne clintcal and rosearch related ectivities, the one of greatest coneern to EPA, NRC, and Huclear Madicine is I-131 as volattle I,. The foar it that gasoous [-13] Will be innaled and absorbed ehraugh the lungs into the blood, or food, or water, be delivered to the thyroid, and avantunily sause thyrotd cancor. EPA is, therefore, proposing a complex array of masuraments of volatile I-131, with computer proprum which supposediy compute radiation absorbed doses to the thyroids of the population at large. These computar prograse contain so many assumptione as to rander eotncidantsi any rasanbiance of these ealeulations to reality.

In addition, EPh appears to have fgnorad a potantially algntficant source of I131 gas, that is, the partent $(1,2,3)$. Nal-131 in eeld solution generates $l_{9}$ 131. That 1s why the current solutions are bastc; the volatility is reduced by a factor of about $100(4)$. When a patient swallews kal-i3l, contact with actdie 
sastric secretions may generate l $_{2}-131$. The pationt ay belch or pass gos containing $I_{2}-131$. In addition, $1-131$ sppears in urine, foees, sweat, saliva, tears, and nasal fluid. The EPA proposed concept of nensurenint is not even romotely practical for mossuring contantnation from potfonte.

In contrast to what EPA has proposed, NRC has deelded that if one is worried about I-13I reachling the thyroid, one should messure 1t. NRC has mandated that we messure the I-I3I burden to the thyrotd of those workers at risk far contamination (10 CFR $35.315(2)(8)$ ) and mintain wittan records of these masuracents. Thase records are reviewod durting inspections by MRC/Agmament State personnel. Burdens of $0.04 \mathrm{uCl}$ constitute aetion lovols" raquiring dostwetry, cause of exposure, and rewedial actions (USMitc Rigulatory Gulda 8.20. 1979). The radiation absorbed dose from 0.04 461 I.131 in the thyrotd is 6.5 mrem ede (E). Nuclear nudlethe personnel are constantly exposed to I-13I by preparing and/or adinistering 1.131 doses and from airborme 1-131 in thetr dupartments, and thus rapresane the worse ease of both worker and generil publif. These workers are assayed mitiple tlwe per year, frequently quarterly and occastonally as often as bi-wonthiy. If nerily all these workere have far less

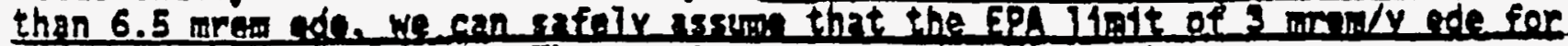
the public is satisflad, The regulation is rodundant at best.

Becaust of the stringent safoty requireants inposed by HRC on radiation workars, it is highiy unifkely that a stoniffeant thyruid burden to workers or the publie wili occur. Requirements for hoods, minimu permissibie flow rates, exhaust filtars, striet isoiation of patient waste, and eppropriate oducation of rediation workers have been highiy successful in proventing sientficant thyrotd contamination. For examole, consider the wdieal worker at highest risk, the nuclear pharanetst. The largest nuclear pharaney che in in the United States has 84 pharmacies and 300 nuclear pharmetsts. They propared 30,000 thorapy doses of I-13I and handled narly 600,000 act I-131 during the period october, 1988.

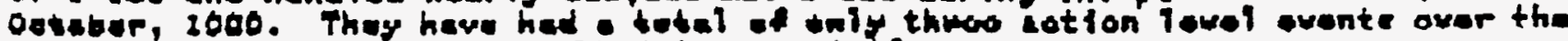
past 5 years (6). Hone resulted in reportible overexposure.

Inspection data for madical 1 leonsess show that there is no ovidence that workers (or the pubitic) are being exposed to hezsrdous environantel levels of $1-13$ I (7).

We muse make one last erucial point aboue the mathed of KRC rogulation of I. 131 contanination. It 18 axtromaly inxornstye. No now equipmant is noeded. The radiatian datoction oyctem utod for thyrota bioussy of radiation workers is the same as that used for radiofoding uptake masurownts in patients. The

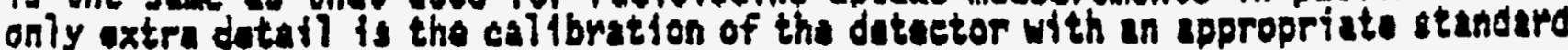
source. This is not vary costly.

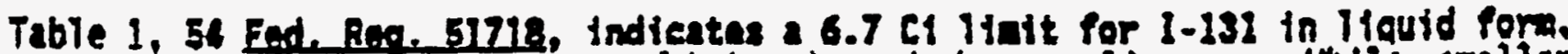
below which an institution would be deand in compliance. while sallor Aospitels nay not approseh that linte, nestor of larger tortiary eare tecehting hospitsis do and would thus be forced to activaly masure to desonstrate compl fance with Table 2 , page 51714.

The proposed EPA requlations would thus be exeecdingly exponsive, and contribute nothing to the pubife health and safety in return. buke University, for examplo, has extimated that it would eset approximately 8500,000 to comply with the proposed EPA reoulations. The cose of providing hositheare has escalated dus to sectatel fretarg guch is compliance with quality assurance mandates, incressad salartes for auxtliary persennel brauth on by mopewer shomsese, and inflation, 
none of which are reimbursabie. Any legisiation, such is the oroposed EPA Regulations, whtch have stgnifleant economic impect on the delivery of - ssential adital servfeas aust include some reasonable assurance that a source of funding axists. It would appear more 13 kely, howaver, that madleal Institutione, to absorb these costs, would nead to reallocate the money from othor vital uedicel services to support this effort, agetn to the detriment of publtic health.

Furthemore, the cost of production of 1-131 by radiophamaceuteal annufacturers would escalate stlli further. Givon the compliance with HRe regulations for ractors, low lovel radiosctive waste disposal and monatary requiroments has incrased the cost of I-IJI tenfold in the last twelve yanre. Wo boliove that many modicel institutione will stop using $1-131$ for ondical purposes rathor then roalfocate scarce resourees causing shortages in othor areas which ire often already underfunded.

Consideration must be given to the number of patients whe raceive I-131 proceduras and the inpact on then if these servieas are daeressed.

Of the estimated 8.5-10 anillion nuelear mediethe proendures parformad ozeh year (not counting radioimonoassay) (8,9), approxianatly 500,000 = 600,000. are thyroid uptakes and scans $(9,20)$. Although in the past these were all parformad with I-131, at present only sbout 100,000 ure done with $1-131$ (9). These involve low administered activities of $1-131$ and do not constitute an environiantal hazard'. The use of I-13I for tharapy of hyperthyratdise (3-30 aci), diagnosis of thyroid carcinom atastases (1-10 xi), and thorapy of thyroid cancar (100. 200 mCl) involves mech highor activities which are therefore of potantial environantel coneern. The eoesl quantity of 1-131 ndmintseerad to paetents per year in the United States is $1000 \mathrm{CI}(6)$.

In 1974, the provelence of thyraid cancer in the United States was about 390 par atilion and there ware about 13 deaths from thyrotd cancer par willion population $(14,15)$. The prevalence has decreased, and according to the American Cancer Soeicty, we can expect $11,300 \mathrm{now}$ cases por year (45.2 per milltan) and 1,025 deaths per. year (4.1 por million) in 1989 in the Unitad states (16). He troat about 1200 now thyroid pationta/yezr (17) and administer about 5000 I. 131 treatments/year for thyroid canear and ontastases (6) and porform about 10,000 metastat fe surveys/year (6). I-13I Is an oxeoliant treatment for thrroid cancer, espectaliy when aduinistered early in the course of the discase. One of the contrlbuting factors to the low wortality of thyrold cancer is the

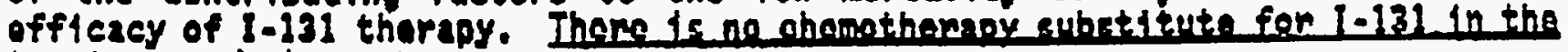
treatment of thuroid encer.

INuelear adteine phystctans matniy use I-123-sodiun lodide or Te-99on pertachnetate instead of I. I3I sodith fodide becuse the former rdiopharmaceuticals have significantly lower radiation absorbed dose to the patfent than the latter. The use of I-13I nevartheless should not be a cause for concern. A recent study published by the fon conter for Dovices and Radiologieni Haith (II) in wich 3503 childrun and idolescents who reeeived dinenostie doses of I-131 ware followed for 93,443 porson+years shows no statistically signtficant inerease in thyroid cancer attribut. able to radiation in these children as compared with appropriate controls. This has been shown in aduit subjects as wil $(12,13)$. 
Hyperthyroidfs is extramely camon in the United States. Frow 1946-1981, approximately 1,000,000 hyperthyrold patients were treated with I-131 (18). Graves' discase the nost common type of hyperthyroldian, is primarliy a disease 300 pregnanctes (19). It has a provalence of 1 in patfent). Kucleer . (Barbara Bush is our aost recent fuwous Graves' disease doses for hyparthyroidicine phystcians adaintster about 35,000 1-13! therapy

Hyperthyroidise may be controllad with non-radioactve anti-thyroid drugs but side offeets, which are trequent and often very sartous, provent the use of these drugs on a permanent basts. Surgery was the trastwent of choice before I-131 becum avallable, but because of morbldity (such as hypoparathyrotdism and recumrant laryngeal norve damage), discoafort, expense, and risk of death from anesthesia (about 1 in 10,000), it is not canonily porforned in the United States for this indication. I-13I therspy is safe, painless, ffective, mech less expensive than surgery, and is thus the treatsent of cholce. Untreated hyperthyroidism may resuit in morbidity from severe proxtani muscie weakness. cachexia, and complicattons of atrial fibrillation. It way also result in death from cardiac arrhythmies leading to myocardial infarction or stroke. [-13] cures hyoenthrroids sm and its avatiability mest continue for effect tye ortitent care.

A Pinal issue we would ask EPA to consider is the meghitude of the radtobtologte EII hazard of I-131. The proposed EPA ragulations are based on a judgment that no mambars of the public should ineur a highar probability of cancer than $1 \times 10^{-}$ t. The recomended maximum 1-131 absorbed dose of 3 mrew/y ede would result in ahly 0.0042 thyroid cancers par 10,000 persons por yasr, suggost ing thet the EPA limit is more than two orders of magnitude too low. potential and the actual carefinogente potential realized by the 3 orea/y ede findt, and the fact that most treated thyroid cancers are not fatal, Eph should realize that the preposed standards are ovor 1000 times stricter than necessary to avold a fatal thyroid cancer rate of $1 \times 10^{\text {ta }}$.

This caiculation was ade using the cht?dhood (not aduit) risk of thyroid carcinoma from I-131 reported by Maxon at ai. (21) of 0.06 casas per mitlion persons per ren to the thyroid per yaar. The thyroid absorbed dose corresponding to 3 arew ode is 100 mras for persons age 1 to adulthood (5). The rtsk is thus 0.06 (70) $(0.1)=0.42$ cancers per atilion people per io: mran to the thyroid each year par year or $0.0042 \times 10^{-7}$. Perhaps the original EPA calculations were based on assuming carcinogenic equivalence of external irradiation data. However, this is not the case in patients treated with I-13] (231,22), and date fros the Harshall Islanders (23) supports this as well. Ren for ren, the thyroid carcinogenicity of I131 is $1 / 70$ lhat of external trradiation (1.9., the Rat for $1-131$ is 
Consideration must be given to the thyrotd careinoma risk per NRE standarde. The action level for radiation workers for NRC I icensees corresponds to 6.5 mrem ede, or a risk of thyrotd carcinom of $0.0053 \times 10^{-}$, assuming this levei of radiation absorbed dose oceurs in a radiation worker eyary year for 10 vears and assuming childhood radfosensitivity. This worst posstble case in an aduit

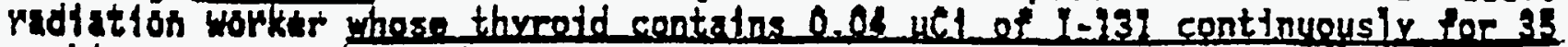
working years and who incurs a total of 55 years of risk at an adult rate of 0.05 cases par williton persons par rea to the thyroid per year. His total risk of a thyraid cancer is $7.5 \times 10^{-4}$ and his total risk of 1 fatal thyroid cancer is just under $1 \times 10^{-6}(39)$. It 18 evident that WRC safety standards for rndintien workens are woll within the Ifmite judged appropriate by ERd for the onnerl aublife. Tharafore, as a result of strict NRC 1inits for radiation workors, the general public has aver a thausand times less risk than nrnnnspd hy FPA as an

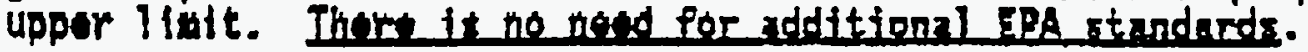

Thare ere probiems with radtonuelides other than I-131. ATthough wost comuntty hospitals would appear to have no difficulty comlying with standerds proposed in Tabla 1, som larger madical centers will. Horeover, the iapact upon radiopharmaceutical houses, which supply radfonuclides and central radiopharmecies distributing these agents would be devastating. It will take considerable radiation safoty offleer (RSO) time for preparation of the EPA oquivalent of NRC T. Teanse anndmants in order to demonstrato compliance with EPA standerds, especially sines the EPA standards are not compatibie with hospital practice.

Technitfum 98m (MaTc), a generator produced radionucilde, is the workhorse of nuclear andicine. About 7.5 million studies are performad annually and grast care should have been given to ragulating an agent of 4 ts extreise inaportance. The possession 7 intt is only $1400 \mathrm{Cl} / \mathrm{y}$. Radiopharacecteteal houses, contral radiopharmefes and why hospitals with ovar goo beds will oxend ents linit. especially if one, which decays in situ vithin the oanarator. is considared as part of the total. The probien stems from in inappropritetiy high estimate of aerosolization of co Te pertechnetate, based upon a single paper published io yoars sgo in Scotland ustng generator that is not available in the U.S. Not oniy is the assumption and that the agent is a liquid (it is a solution), but it is virtually naver exposed to room air. even after it is eluted from the generetor, Inhaling and totaliy obsorbing whole cubic meter of air would rasult in a burden of 1.7 nCt, with its whol body dose of 0.00011 Ran (brsed upon manufacturar's paekage inserts). It would require inhelation of 900,000

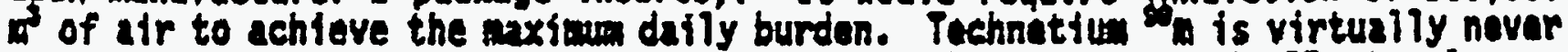
oxpased to atr tn the fimse place, so atrborne feveis ary eypteally too low to messure. The biological affuet givan the six hour hatf iffe and monochromatic ganua ray is nintarl. Heasurement of any single radionuclide in an atmosphere such as a nustear andisine dopartmont cannot be done because of other potentially contaninating agonts.

Xenon $133(X 0-133)$ is used for inhelation lung laxging over half a million timas per year and is boginning to assum arjor imortance in organ blood flow studias to the heart and brain. The Iinft is onjy $62 \mathrm{Cl} / \mathrm{yr}$. Because Xanon, is a noble gas, it has virtualiy no bloaffinity. The radistion exposure is thus vory small even for the pattent who inhaies wiflicurte doses direetiy. The Compl lance Guide does not list any filtar systom for Xe.133 that olves highor than a sow decrease in $\mathrm{Xe}-133$ concentration. Although the proposed reguiations do include a factor 
of 10 raduction in airborne ontssions if activated charcost. Is usad such flltors are orders of magnitude more effictent. 250 's wili have to make weasurements to prove this and seek wivers from the listed Xe-133 Iintts. One 500 bed hospital ineluded in this survey that has an active brain imaging service uses 2.9 times the maximum listed quantity of Xonon ser year. It does not evan use this radiopharaceutical for ventllation studies. An EPA license amendmont based on documentation of fifter effectiveness will be necassary to continue this activity.

Carbon 14, in important research radionuclide, is rastrieted to $290 \mathrm{Ci} / \mathrm{y}$. Although the limit is not a problom for most facilitfas, it could be detrinontal for certain large institutions and radiopharaceutical manufacturers. Liquid 1-125, with its 6.2 C livit, will be even wore a problem than Carbon 14.

We have endeavored to produce a reslistie oconosic fapact study. to ascortain the cost of complying with this duplicative EPR requlatory proposal. In order to do so, we obtainad a capy of the couply progren and the complifance Guide and perforwed sample calculations for several types of hospitals. While it appears to be the case that small comunity hospitais with ilited nuclear medicine services will be axompt from having to roport at all, the reporting raquirement will tmpact grently on many hospitals with severcl hundred bods and greater, inciuding medical conturs with research activitfes. Host modical licensees wili not be required to mansure airborne contueination on 1 ine, but 450 of $1-131$, -Te, and $x e-133$ is of surficiont quantity in any institutions to warrant formal yearly raporting and informing EPA of any plans to altar institutional structures that impact on radionuclide use. Aithough this will not be an insurmountable burden for most institutions, the costs in any cases will not be negligible.

For example, one way to cope with EPA's l-13l limits is to switch from using $\mathrm{NaI}-131$ in solution to $\mathrm{Nal}=131$ in capsules, bacause the CosPLY program treats capsules as solids and peraits 1000 times aore actjuity to be used por year in this form rolative to lloutds. Howner, Mal-13l capsulat are coproxinately twica as costly as NaI-131 in solution, and this cost will have to be borno by the patfent or the patient's haith insurer. Use of capsules is very popular despite cost because most users are excmet frem thyroid bloassay mencurements if capsules are used instead of ltautd. Noout 75\% of Hal-131 doses are in capsule form already. The exclusivo use of capsules will resuit in an added cost of about $12.55 \%$ on the average. An altamative to EPA's I-131 linits is the use of a charconl flltor, which gives the institution an extre factor of 10 in activity linits. Howver, it costs suveral thousand dollars to upgrade an existing hood to ono using setfuatad chareoal.

In addition to costs such as those itenized above, It will take the Radiation Safoty offlcar soveral parson days, (or about l-2\% of his yearly sctivity) to comply with EPA reporting. The colPLY progran raquires considerable dotall, colfoetion of which te tias consuming. Furthermors, the impact upen proposed construction and ranovation is extremaiy severe.

EPA appours to have underestiated the anount of puper work that will be involved. Not only will any nore users have to roport than EPA expects, but the number of amendments for variances will be vary large. Given that EPA nust 
approve uny new construetion or renovation that will contributs wore than is of the 11 mit, this will further tncrease the paper work burden on EPA.

Use of radionuclides, nost of which are byproduct aterial, is alraady tightly regulated and carefully by the HRC. The licansing and Inspaction progrums carried out by that body provide an excollent margin of public safety. The new regulations are simply redundant, and as EPA dowits, they are also inconsistent. NRC dofines releases on an activity per volue basts, EPA on exposure. Givan the vast difference in dose equivalents frow vartous radionuclides based upon physteal half $11 f$, decay spectrum, and biodistribution, considerable effort and expense would be expended to satisfy the different date sets and compliations required by the two regulators.

Therefore, the Soclety of Nuclear Medjcine and the American College of Nuclear Phystcians seo absolutely no rationale in favor of dual regulation. The NRC has been protecting the publite at a higher level than EPA proposes for over 30 years. Dual regulation will only eccouplish additional expense, linitation of medical resources, and tncreasid risk to the pubitic health and safaty is a result of these liattations.

Based upon the foragoing, ACHP and SMA respectfully request that the portions of 40 CFR 61. Suct ton 112 relating to NRC 1 icansees be reconsidered, and that the EPA withdraw from regulating these facilities in fovor of the NRC. 


\section{RERINunss}

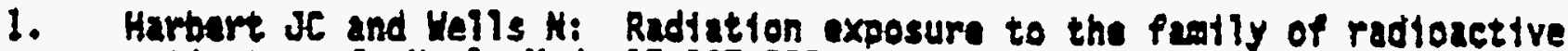
patfents. J. Hucl. Hod. 15:887-888, 1974.

2. Jacobsen AP, PIato PA, and Toeraek D: Contumination of the howe environwent by patients treated with fodthe-131: Injtial rasults. Amer. J. Public Heith 68:225-230, 2978.

3. Shaptro $J$ and Mosller OW: Population exposures from radionucildes in medicine---as low as reasonablo echtevable? (Editortal). Anar. J. Public Health 68:219-220, 1978.

4. Luckett LH and Statler RE: Radiolodine volatflization from roforwulatad sodfun todide I-131 oral solukton. J. Huel. Mad. 21:477-479, 1980.

5. Intornationel Counisston on Radiological Protection (ICRP) Publication 53: Radiation Dose to Pattents from Rudiophanaceutieals, Pp.259-278, Pergason Press, Elwsford, NY, 1988.

6. Parsonal comunication (Jack Coffey) and corporate datx, Syncor, Ine., Dec., 1989.

7. Records of the Huclear Regulatory Coumission (coupriting the five regions) and records of three Agreanent states (Califormia, Texas, and Florida).

8. Human Rasoureas Survey of Nuclear Hedtcine Technologists, 1984. Pruparad by the Humen Resource Task Fored of the Tuehnolootst Sertinn, The Snefinty of Nuclasr Medicine, Jour. Nuel. Med. Technol. 13:Ho.3, Sapt., 1985. Used in NUREe-1272, Yol.3, No.2, Office for AnaTysis and Evaluation of Operattonal Datz, 1988 Annual Report, June, 2989. U.S. Nuclear Regulatory Comatssion.

9. Personal Comounteation (Henry Krawar, Ph.D.), "Warket Measures Trend Datax, 1984-Dee. 6, 1989, Medt-Phystcs, Inc.

10. Mattonal Counctl on Radiation Protection and Measurentents (NCRP) Report No. 100: Exposure of the U.S. Population from Disgnostic Medieal Radiation. Tabie 4.1, p. 32. MCRP, Bathesda, MD, 1989.

11. Kantlton Fi, Chtacehtorint RP, Kaczoarak R6: A followallp study of persons who had I-13I and other diagnostic procedures during childhood and adolascance. HHS Publication FDA 89-8276, Aug., 1989.

12. Holm LE, Lundall G, Walkindar 6: Inetdence of mallgant thyroid tumors in humans after exposure to diagnostte dose of qodino-131. Rotrospective cohort study. J.Hati. Caneer Inst.64:1055-1059, 1980.

13. Holm LE, at 81..: Thyrold cancer after diagnostie dose of J-131: A retrospect ve cohort study. J. Hatl. Cancer Inst. 82:1132-1138, 1988. 
14. Robbins SL: Pathologic Basis of Disease, P. 1334-1336. H.B. Sanders, Phtladelphia, PA, 1974.

15. Third Hational Cancer Survey: Incidence Data, Mational Cancer Institute Monograph 41, OHEW Publication No. (NIH) 75-787. Bethesda, MD, US. Dept. HEW, PHS, HIH, NCI, DP. 107-111, 1975.

16. Amarican Cancer Soctety, Silver Spring, KD, 1989

17. Personal Compuniestion (VIjay Vank, M.D.). Goorge Washington University, Dept. of Nuclear Medictne, Dee., 1989.

18. Beferwalters Wh: New horizons for tharapeutic nuclear adicine in 1981. J. Nucl. Hed. 22:549-554, 1981.

19. Fisher DA: Neonatal thyrold disease in the offspring of women with auto imane thyroid disease. Thyroid Today $2(4), 1986$.

20. Personal Connunication (William Blahd, M.D.). V.A. Wasdworth Medteal Center, Los Angeles, Dec., 1989; also data from Harbor-UCLA Kedical Center, 1987.

21. Maxon HR, Thomas SR, Saenger EL, Buncher CR, and Keriakes JG: Ionizing irradiation and the induetion of elinically significant disease in the human thyrold gland. Amer.J.Hed.63:967-978, 1987.

22. NCRP Report No. 55: Protection of the Thyroid Gland in the Event of Release of Radioiodine, pp.9-12. KCRP, Bethesda, MD, 1977.

23. Canard RA: A 20-year reviow of medieal findings in a Marshallese population accidentally exposed to radioactive fallout. Report No.50424, Brookhaven National Laboratory, Upton, NY, 1975.

24. Saenger EL, Thomas $6 E$, and Thoupkins ER: Incidence of leukemia following treatment of hyperthyroidisa. Preliminary report of the Cooperative Thyrotoxicosis follow-up Study. J.A.M.A. 205:855-862, 1968.

25. Dobyns BM, Sheline GE, Horkman JE et al.: Malignant and benign neoplasms of the thyroid in patients treated for hyperthyroidisa. A report of the Cooparattve Thyrotoxtcosts Tharapy follow-up Study. J. Clin. Endocrinol. Metab. 38:976-998, 1974.

26. Schull WJ, Otake $M$, and Meel JV: Genetic effects of the atomic bombs: A raxppraisal. Sctence 213:1220-1227, 1981 .

27. Frietas JE, Swanson DP, Gross 10 , and Sisson JC: Iodine-131: OptimaI therapy for hyperthyroidisa in children and adolescents? $\mathrm{J}$. Nucl. Med.20:847-850, 1979.

28. Shelline GE, Lindsay $S$, Cormack KR, et al: Thyroid nodules occurring late after treatment of thyrotoxicosis with radiolodine. J. Ciin. Endocrinot. Metab.22:8-18, 1962 . 
29. Kogut ND, Kaplan SA, Collipp PJ, et al: Treatment of hyperthyroidism in chlldren: analysis of forty-five patients. N.Eng1.J.Med. 272:217-221, 1963.

30. Crfle 6, Schumacher OP: Radioactive lodine traatment of Graves' disease: results of 32 childran under 16 years of age. Am.J.Dis.Chtld:110:501504, 1965.

31. Starr $P$, Jaffe $H$, Dettinger L: Later results of I-13I treatment of hyperthyroidism in 73 children and adolescents: 1967 follow-up. J. Nuci. Med.10:586-590, 1969.

32. Hayek A, Chaparan Ex, Crawford JD: Long-term resuits of treatment of thyrotoxicosis in chlidren and adolescents with radionctive lodine. N.Eng.J. Med. 283:949-953, 1970.

33. Goldswith RE: Radioisotope therapy for Gravas' disazse. Mayo Clin.Proc. 17: $953-961,1972$.

34. Safa AM, Schumacher OP, Rodriguez-Antunes A: Long-term follow-up results in children and adolescents treatad with radioactive iodine I-131 for hyperthyroidism. N. Eng.J.Med. 292:167-171, 1975.

35. Safa AM, Schumacher OP: Follow-up of children treated with I-131. K.Eng.J. Med.294:54, 1976.

36. Roburtson JS, Gorman CA: Gonadal radiation dase and its gonotic significance in radiolodine therapy of hyperthyroldisw. J.Nuel . Med. I7:826835, 1976.

37. Guttmacher AF: Fertility of man. Fert11.Steri1.3:281-289, 1952.

38. Sarkar SO, Beiemaiters WH, aill SP, at al.: Subsequent fertility and birth histories of children and adolescents treated with I-13I for thyrold cancer. J. Hucl. Hed. 12:460-464, 1976.

39. Calculations confirmed by L. Milson and E. Watson of Medical Internal Dose Center at Oak Ridge, TH, Dec., 1989. 
American

The Society

College of

of Nuclear

Nuclear

Medicine

Physicians

May 22, 1990

James $B$. Wyngaarden, $M$. D.

Director, Life Sciences

Office of Science and Technology Policy

01d Executive Office Building

17th Street and Pennsylvania Avenue, N. W.

Washington, D. C. 20506

Dear Or. Wyngaarden,

I would like to thank you for the opportunity to meet with Dr. Carol S. Marcus and myself to discuss the Environmental Protection Agency's (EPA) NESHAPs and the issue of dual regulation of Nuclear Medicine and the radiopharmaceutical industry.

He believe that the public health and safety are adequately protected by the Nuclear Regulatory Commission's (NRC) regulation of airborne radionuclide emissions from medical, research and radiopharmaceutical facilities. As we indicated to you, the review of the doses to radiation workers at these facilities and worst case assumptions supports our assertion.

We are, of course, very interested and available to meet with you to respond to requests for additional data. We have not yet determined from the EPA the additional data which may be required to support our beliefs. If additional analyses or data is requested, this must be presented we17 in advance of the July 13 expiration of the stay of implementation.

The EPA and the NRC have publicly stated their support for continuing the current regulation of radionuclide emissions by the NRC. We are hopeful that Congress, during their consideration of pending Clean Air legislation, will be convinced that radionucifde emissions from NRC medical and academic licensees pose no threat to the public and should continue under the current regulatory system implemented and administered by the NRC. An amendment to that effect would be most appropriate.

He believe that implementation of the NESHAPs would impose a significant financial burden to hospitals and radiopharmaceutical manufacturers. EPA did not make readily available the COMPLY program or associated documentation, thus precluding analysis of the assumption or estimation of anticipated financial commitment of the NRC-licensed facilities. A yeariy cost of approximately $\$ 20,000$ - $\$ 50,000$ per reporting institution (i. e., greater than 500 beds, research facility) would have to be allocated for compliance with the EPA 
Letter to James B. Wyngaarden, M.D.

May 22, 1990

Page 2

standards. There are approximately 24,000 NRC licensees in the United States; 3,914 are hospitals with a Nuclear Medicine service. Of these hospitals, approximately $15 \%$ or 600 have greater than 500 beds. Therefore, the total estimated annual cost represented by these institutions in reporting to the EPA is $\$ 21,000,000$ (600 hospitals $\times \$ 35,000$ (the average estimated cost per hospital)\}. Smailer entities (hospitals with less than 500 beds) would have costs of approximately $\$ 5,000$ per year per hospital in order to arrive at the finding of not having to report and to provide sufficient documentation in support of their exemption. However, the costs to the smaller hospitals are cumulatively significant since there are 3,314 NRC medical licensees with fewer than 500 beds; the total annual costs for these facilities would be approximately $\$ 16,570,000$. Therefore, the total estimated annual cost for hospitals licensed with the NRC would be $\$ 37,570,000$. In general, the funds to comply with the EPA program, which has no demonstrated benefit, would be diverted from a hospital's general budget. It is unlikely that the Health Care Financing Administration (HCFA) would make allocations for the increased costs or that additional funds for research would be made available for this purpose.

The radiopharmaceutical industry is also at risk. Since 1980 , the number of companies has decreased alarmingly. Our regulatory environment has transformed an industry created and developed in the United States into an export product. Currently, there are only four radiopharmaceutical manufacturers in the United States; two are foreign owned. The second largest firm may be acquired by another foreign company. The imposition of an additional, costly regulatory burden will further depress the industry. We estimate that costs of radiopharmaceutical products wi1l increase $20 \%$ in order to demonstrate compliance with the additional regulations imposed by the EPA. Given that the total radiopharmaceutical industry in the United States is approximately a $\$ 300$ million market, the total costs to manufacturers, passed onto users, will be approximately $\$ 60,000,000$ (which includes an increase in users costs due to importing products which will no longer be made in the United States). In addition, Mali inckrodt Medical, Inc. has filed a lawsuit with the EPA due, in part, to the inappropriate financial burden that would be imposed.

One of the consequences of the current state of the American radiopharmaceutical industry is that as of February, 1990 there is no longer a national supply of 99 - Molybdenum (used as the raw material for the 99 - Holybdenum/Technetium $99 \mathrm{~m}$ generator). This material is the key element in $80 \%$ of clinical exams and is significant in that approximately 10,000,000 Nuclear Medicine diagnostic studies are performed yearly. We met recently with the Food and Drug Administration to discuss creating a more attractive regulatory environment for American radiopharmaceutical manufacturers. The outcome of that meeting is not yet clear and we hope that progress will be achieved. The increased regulatory burden posed by the EPA would only serve to further aggravate a metastable industry.

The financial requirements which result from compliance with the NESHAPs would al so be significant for centralized radiopharmacies. In the United States, there are approximately 125 centralized radiopharmacies. We approximate the annual cost per facility, due to the EPA reporting requirements, at $\$ 20,000$. Therefore, the total annual cost requirement of the centralized radiopharmacies would be 
Letter to James B. Wyngaarden, M.D.

May 22, 1990

Page 3

estimated at $\$ 2,500,000$. The total estimated costs are aiready over $\$ 100,000,000$ $(\$ 37,570,000+\$ 60,000,000+\$ 2,500,000)$ and do not include costs to the research community or to the radioimunoassay laboratories $(100,000,000$ procedures per year). DuPont, which has most of the research chemical market in the United States involving $\mathrm{C}-14$ and $\mathrm{H}-3$ labeled compounds, will abandon the business if they are forced to meet present EPA requirements. The sole manufacturer would be International Chemical and Nuclear (ICN) in Irvine, California and they would also most likely follow suit. What is the cost of not performing bio-medical research in the United States involving metabolism, biochemistry and pharmacology? In regards to radioimmunoassay (RIA), the major radionuclide is I-125, which is one of the most strictly controlled isotopes in EPA's present scheme. The impact of this has not been estimated as yet.

Your assistance in resolving the issue of duplicative regulatory authority, and recognition of the NRC as the lead agency in regulation of radionuclide emissions from its medical 7 icensees, would be deeply appreciated. As I noted previousiy, if additional data is required, we will furnish it as quickly as possible. In addition, we will contact Mr. Richard Guimond within the next few days concerning his perception of necessary background information for considering our exemption.

Yours truly,

Robert E. Henkin, M. D. FACNP

President

American College of Nuclear Physicians

bec: Robert E. Henkin, M.D.

Richard A. Holmes, H.D.

Carol Marcus, M.D.

Torry Mark Sansone

Virginia Pappas

Carol Lively 
APPENDIX 2 


\section{APPENDIX 2 \\ Summary of Regulation}

EPA: 40 CFR Part 61

National Emission Standards for Hazardous Air Pollutants; Radionuclides; Final Rule and Notice of Reconsideration

(Federal Register 54: 51654-51715, 12/15/89)

Subpart I - National Emission Standards for Radionuclide Emissions from Facilities Licensed by the Nuclear Regulatory Commission (NRC) and Federal Facilities not covered by Subpart H...

\section{Applicability of Subpart I}

Any facility licensed by the N.R.C. or any Agreement State to receive title to, receive, possess, use, transfer, or deliver any source, by-product, or special nuclear material.

\section{Standard}

- Emissions of radionuclides, including iodine, to the ambient air from a facility regulated under this subpart shall not exceed those amounts that would cause any member of the public to receive in any year an effective dose equivalent of $10 \mathrm{mrem} / \mathrm{yr}$.

- Emissions of iodine to the ambient air from a facility regulated under this subpart shall not exceed those amounts that would cause any member of the public to receive in any year an effective dose equivalent of $3 \mathrm{mrem} / \mathrm{yr}$. [NOTE: Limit is equivalent to $100 \mathrm{mrem} / \mathrm{yr}$ dose equivalent to thyroid tissue.]

\section{Compliance}

Determined by use of either EPA's COMPLY computer code or EPA approved methods for satisfying alternative requirements limiting annual possession quantities or concentration levels.

EXAMPLE: iodine-131
Annual possession quantities:
$(\mathrm{Ci} / \mathrm{yr})$
Gaseous form
$6.7 \times 10^{-3}$
Liquid/powder forms
6.7
Solid form
$6.7 \times 10^{3}$ 
Concentration levels: $\left(\mathrm{Ci} / \mathrm{m}^{3}\right)$-- stack or vent emission estimates $2.1 \times 10^{-13}$

\section{Reporting Requirements}

- Annual report to EPA (calendar year by March 31) containing information on:

details on any relevant construction and modification

responsible persons

radioactive materials used

handling and processing procedures

release configurations and controls

nearest occupied building - type of use

nearest food form and products

calculated effective dose equivalent

physical form and quantity of radionuclides released

stack/vent description and operation

dimensions of facility buildings involved in releases.

o Facilities releasing less than $10 \%$ of dose limits exempt from above reporting, provided annual dose determination of eligibility is performed.

- If facility not in compliance, monthly reporting required until facility in compliance.

- First report will cover 1990 calendar year emissions.

\section{Recordkeeping}

Documentation of sources of input parameters, sufficient to allow verification by independent audit of compliance and/or qualification for exemption. Records must be maintained for five years and be available for inspection.

\section{Application to Construct or Modify}

Application for approval of the construction of any new source or modification of any existing source covered under Subpart I must be made according to Subpart A, unless either total emissions from facility are less than $10 \%$ of limits or results in an increase of less than $1 \%$ of limits.

\section{Emission Determination}

- Measured radionuclide emission rates from point sources according to

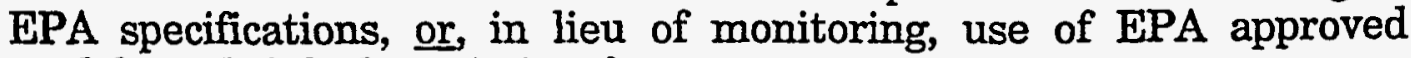
models and default emission factors. 


\section{APPENDIX 3}


Date

From

Subject

March 28, 1989

Acting Chief, RSB, DS

EPA Regulation of Radionuclide Emissions to the Atmosphere

NIH and DS Management

on March 7, 1989 the United States Environmental Protection Agency (EPA) published a Proposed Rule and Notice of Public Hearing (40CFR61) on the subject of Regulation of Radionuclides for compliance with the provisions of the clean Air Act. This regulation applies to all NRC-licensed non-Department of Energy Federal facilities. It is quite clear from my reading of the Federal Register Notice and the associated background documentation that the NIH will be subject to the compliance and reporting requirements of this rule. Interested "persons" are invited to provide comments on the rule by May 15, 1989. In addition, there are public hearings on April 11 and 12 in Washington, D.C. and in Ias Vegas, Nevada on April 13 and 14. Any "persons" wishing an opportunity for oral presentation at these hearings must notify EPA by April 3, 1989.

In my opinion, based on a review of the compliance requirements of this rule, a SUBSTANTIAL IMPACT on the research and medical programs at NIH could be realized if the rule becomes law in any of its three proposed approaches. In any event it appears that the burden of compliance achievement, documentation, and reporting will, as usual, fall within the scope of the NIH Radiation Safety Program. The demands of compliance verification and reporting as described in the proposed rule are so extensive that, for a program of our size and complexity, a MAJOR data collection, analysis and reporting effort will be required, demanding substantial in-house or contract dollar resources.

In a nutshell, the EPA was required by a DC circuit court to propose "regulatory decisions" regarding the standards for emissions of radionuclides from certain source facilities by $2 / 28 / 89$, and to take final action by $8 / 31 / 89$. The proposed rule and its background documentation, including a pC-based computer code for determining compliance, was issued on March 7. 1989. The rule proposes exposure standards for an aggregate effective dose equivalent (EDE) to the nearest receptor from all pathways, including food consumption, from airborne radionuclide emissions in subject facilities at the following levels: 
Either:

1) $10 \mathrm{mrem} / \mathrm{yr}$ (Approaches A \& B);

or, at the discretion of the Administrator

2) $3 \mathrm{mrem} / \mathrm{yr}$ (Approach C):

or

3) $0.03 \mathrm{mrem} / \mathrm{yr}$ (Approach D).

The recommended level is $10 \mathrm{mrem} / \mathrm{yr}$. It is required that each facility's compliance with the EDE limits be determined by analyses of each radionuclide emission in each possible physical form from each stack or vent to each potential dose receptor. Compliance is determined by a tiered approach. At the first tier, a comparison is made of annual activity used vs. table values for each radionuclide as provided in a compliance guide. Based on the annual receipts of radioactive materials, NIH would certainly exceed the values in the table.

At the second tier actual concentrations of nuclides emitted from stacks, as đétermined by measurements, are compared to a table of concentration levels for environmental compliance. The sum of the fractions of actual concentration divided by compliance value must be less than 1 for each release point. There are two problems with this approach for NIH:

1) the concentrations of only a few radionuclides out of the entire universe of nuclides received by NIH are measured regularly (namely $\mathrm{I}-125$ and $\mathrm{H}-3$ ) from only approximately 70 release points, and

2) the EPA compliance concentration levels are dramatically lower than existing 10CFR20 Maximum Permissable concentrations (MPC's) to unrestricted areas, (e.g. a factor of 1000 for $I-125$ ).

Thus, the NIH does not currently have the capability for the measurement data to demonstrate compliance in this tier for all possible release points and nuclides: and our existing measured data, in some cases, indicates higher concentration levels than allowable under the rule (we often see fractions of current MPC's, such as $10 \%$ for $I-125$ ).

The third tier of compliance assessment, used in the absence of measured data, requires that the annual possession amounts for each nuclide be appropriately multiplied by factors (preset by EPA) to establish the potential airborne fraction (example: 0.001 for liquid form nuclides), then divided by the air flow 
in the vent to establish a concentration for comparison with compliance values. I assume that NIH would be permitted to "distribute" the 33,000+ shipments of material received among the buildings where the activity is used, and employ flow rates from each building or building sub-module to establish concentrations. If we are out of compliance on this basis, (and I suspect that we would be based on the quantities of material used), we can use Ievel 4 of the EPA supplied program COMPLY to determine if we meet the standards at receptor points. The complication with this is that we would need to define receptor locations, surrounding each of potentially hundreds of stack or vent release points and run the calculations for the list of controlled nuclides. The doses calculated would probably be additive for receptors subject to releases from multiple release points, and we would probably exceed the standards. It is not clear what action EPA would take if the analyses demonstrated non-compliance, but most likely NIH would be required to achieve compliance by adding engineering controls to emission points or reducing usage of given nuclides an an annual basis in the buildings where releases lead to non-compliance.

The NIH should submit comments to EPA on this proposed rule by the deadiine of May 15, 1989. RSB will prepare a discussion of the potential impact of this rule on radionuclide use in biomedical research and clinical treatment at NIH and in general. The focus of this discussion is anticipated to. include:

- The economic impact on research (we anticipate a data gathering, analysis and reporting impact of several hundred thousand dollars initially, with recurring annual costs of nearly $\$ 100,000$; compliance costs may end up exceeding a milition dollars).

- The potential delay in progress of research into the causes, prevention and treatment of human diseases caused by the implementation of these requirements.

- The potential effects on the treatment of patients for diseases such as cancer, using radionuclide therapy.

o other issues that the implementation may affect.

It may be prudent to consider commenting on the validity of the dose limits chosen, $i . e$. are they unnecessarily low? The Radiation Epidemiology Branch, DCE, NCI may be capable of providing some guidance and credibility in the presentation of such an argument. 
The comments should be submitted for signature by an appropriate representative of the Director, NIH or by the Director personally.

We are prepared to present a briefing to interested NIH management representatives if requested. Please contact me at $\times 5774$ if you desire further information.

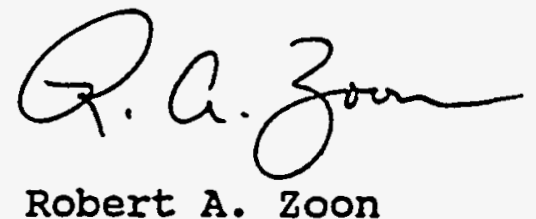

cc: Members, NIH Radiation

Safety Committee

Acting RSO, NIH

RSB staff 
Comparison of Air emisson standards
(ulli/cc)

Dose $\rightarrow .01 \mathrm{rem}$
limit

5 rem

Irem

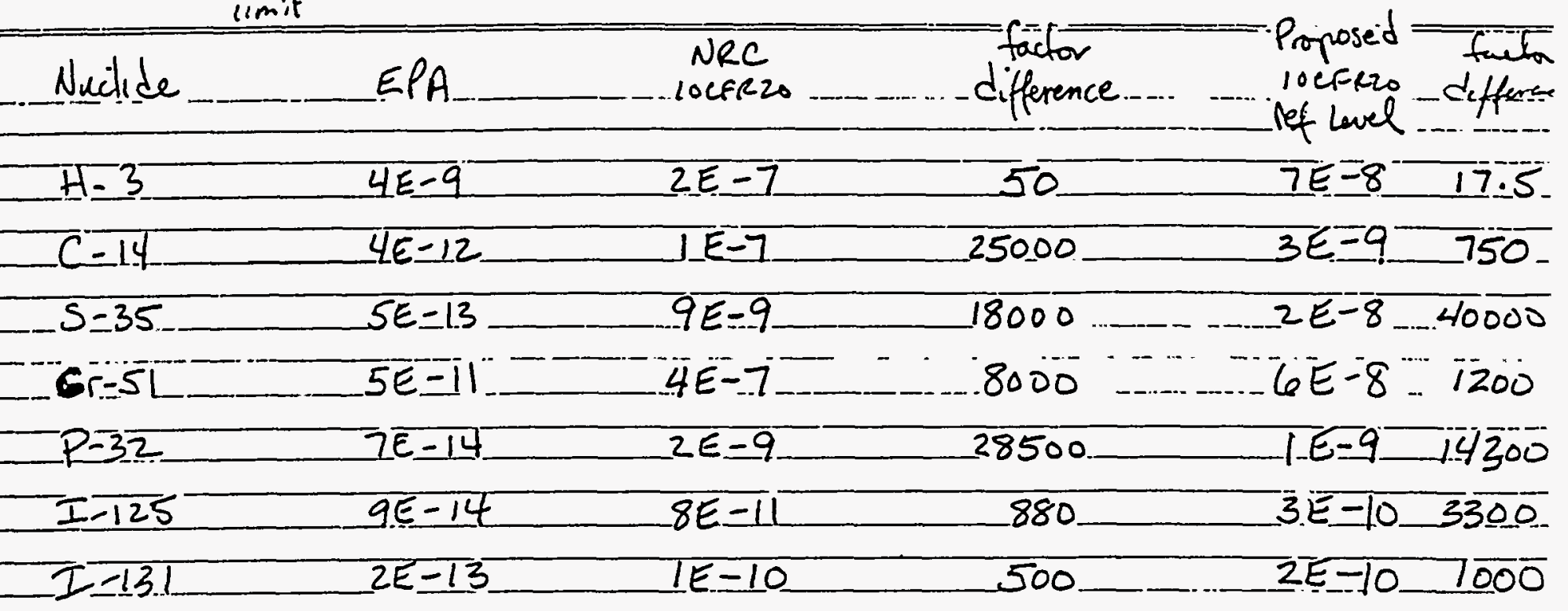


Summary of the Proposed EPA Regulations for Compliance with the National Emissions Standards for Hazardous Air Pollutants (NESHAPS) in 40 CFR 61, Subpart I.

- The National Institutes of Health strongly urges the EPA to reconsider an exemption of medical treatment and research facilities from the provisions of 40 CFR Part 61 related to radioactive air emissions through a finding that existing regulatory and voluntary controls provide an ample margin of safety. Such a decision was made in the case of high-level nuclear waste facilities under Subpart F of the regulations.

- The Regulations increase risk by imposing unreasonable restrictions on the use of essential isotopes used in medical diagnosis, treatment and research.

- If even a single hyperthyroid or thyroid carcinoma patient is affectod by the implementation of this standard, the benefit/risk balance is negative. EPA's risk assessment indicates that no reduction in incidence would occur and only a small reduction of the MIR (Maximum Individual Risk) would occur if current emissions were reduced to those proposed by EPA.

- Although EPA has shown that an ample margin of safety already exists for those facilities in Subpart I, they state in their Federal Register notice, dated December 15, 1989, that "EPA has decided to continue regulation of this category to insure that current levels of emissions are not increased."

- Superimposing complicated, resource consuming requirements to prove compliance with unnecessary regulations could discourage the use of radiopharmaceuticals available to physicians and is not in the best interest of the public or the practice of medicine.

EPA ignores its own goal of an MIR of $1 \times 10^{4}$. Using the currently accepted risk factors, the EPA suggested maximum for adsorbed dose from ${ }^{131} 1$ of $3 \mathrm{mrem} / \mathrm{y}$ ede would result in only 0.0042 thyroid cancers per 10,000 persons per year, nearly two orders of magnitude below the EPA limit.

Regulation of medical treatment and research facilities by the NRC already achieves emission level controls far below those proposed by EPA. Additionally, NRC requires actual measurements of uptake by personnel at the greatest risk of exposure as the method of proving compliance rather that a computer code containing numerous assumptions. NRC's method has been highly reliable over a number of years.

In a joint response to EPA's request for public comment, the American College of Nuclear Physicians (ACNP) and the Society of Nuclear Medicine (SNM) state that the Comply computer code "programs contain so many assumptions as to render coincidental any resemblance of these calculations to reality."

The cost to comply with the new regulations will discourage medical research and patient treatment using radioactive materials. In the ACNP/SNM public comment they state "The proposed EPA regulations would thus be exceedingly expensive, and contribute nothing to the public health and safety in retum. Duke University, for example, has estimated that it would cost approximately $\$ 500,000$ to comply with the proposed EPA regulations." 
National Institutes of Heaith Bethesda. Maryland 20892

Building

Room

(301) 496 .

February 9, 1990

Central Docket Section (A-130)

Environmental Protection Agency

Attn: Docket No. A-79-11

Washington, DC 20460

\section{Dear Sir or Ms:}

In accordance with the opportunity to submit comments on the proposed amendment to 40 CFR Part 61, issued March 7, 1989, the National Institutes of Health (NIH) provided cominents to the Environmental Protection Agency on May 11, 1989. Those comments were based on a brief review of the available documentation, due to the severely short time constraints imposed by the court order under which EPA was issuing the standards. In addition to NIH's opposition to the standards based on the fact that existing regulations of the Nuclear Regulatory Commission (NRC) and the Agreement States provide an ample margin of safety for the medical and research uses of radioactive materials, we were particularly concerned with the potential effect that the regulation would have on the use of radioactive iodine 131 in the therapy of hyperthyroidism and thyroid cancer. We based this concern on a parametric analysis of the COMPLY code, using individual nuclides and release to receptor scenarios to determine which nuclides contributed substantively to the controlling effective dose equivalent (ede). Our analyses revealed that the radioactive iodines, particularly I-125 and I-131, were the controlling nuclides in the calculation. In addition, it seemed that the risk-based standard setting methodology used by EPA only considered the inherently negative factors in the use of the radioactivity, i.e. effect of dose on incidentally exposed populations to airbome releases. No consideration was given of the life-saving and life-prolonging factor of use of the radioactivity in therapy.

I-131 is the most effective treatment for hyperthyroidism, which occurs in about 1.5 percent of the population. Alternative therapies are antithyroid drugs which have toxicity and require long term continuation, and surgical thyroidectomy, which is more costly and more dangerous to the patient in terms of morbidity and mortality. The effectiveness of I-131 in the treatment of thyroid cancer is an additional factor. In the United States there are approximately 10,000 new cases of thyroid cancer per year. After initial surgical removal, ablation with I-131 is used to complete the thyroidectomy in at least half of these patients (i.e. $~-5000$ ) in doses ranging from 30 to $150 \mathrm{mCi}$. Most of these patients then receive one or more test doses of I-131 (2 to 10 $\mathrm{mCi}$ ) to detect the occurrence of metastases. A conservative estimate of the number of patients who develop metastatic thyroid cancer who could benefit from I-131 therapy is 2000 new cases per year. These patients receive from one to ten treatment doses of 150 to $300 \mathrm{mCi}$ over a period of up to 20 years or more. This treatment is curative in some cases and prolongs diseasefree survival in many cases. Alternative treatments for metastatic thyroid cancer are external irradiation, which is less effective than I-13I and can be used only when metastases are localized; 
and chemotherapy, which is only partially effective and cunsiderably more toxic than $1-131$ therapy.

The National Institutes of Health again requests that the EPA consider an exemption of medical trearment and research facilities from the provisions of 40 CFR Part 61 related to radioactive air emissions through a finding that existing regulatory and voluntary controls provide an ample margin of safety. The NIH believes that imposition of the new EPA NESHAPS on NRC medical and medical research licensees is not only unwarranted but could have a negative effect on the treatment and survival of some patients. It is our position that the current NRC regulatory program insures an adequate margin of safety and that additional regulations constitute a wasteful use of scarce medical resources. To superimpose complicated, resource consuming requirements to prove compliance with unnecessary regulations which could discourage the use of radiopharmaceuticals available to physicians is not in the best interest of the public or the practice of medicine.

In our original comments NIH expressed the opinion that the implementation of the rule for NRC medical and medical research licensees could have an impact on patients and could result in an increase in mortality for both hyperthroidism and thyroid carcinoma. The NIH was not alone in expressing this opinion; similar concerns were expressed by the Society of Nuclear Medicine and the American College of Nuclear Physicians. While granting a period of reconsideration based on this contention, EPA has nor indicated in the notice of December 15, 1989 that they have considered or investigated these genuine concerns. We again request that EPA address these concerns as part of the public record and provide any supporting technical basis for the contention that there will be no negative impact on medical care from the implementation of the rule. The relatively low annual maximum possession limit for automatic compliance (i.e. no reporting) for I-131 (6.7 Ci.) may dissuade medical treatment facilities from using that isotope and to resort to use of other, less effective, but otherwise recognized treatment modalities. A small but definable increase in patient deaths could result, completely overshadowing any benefit from the rule. The EPA admits in the Federal Register Notice (54 FR 51654) "In this source category, almost all of the incidence comes from people whose risk level is less than $1 \times 10^{-6}$. This means that small reductions in the emissions of a few licensees will have little, if any, effect on the number of health effects, both fatal and non-fatal, in the population." In fact according to EPA's analysis of model facilities, in the hospital sub-category the risk level never exceeded $1 \times 10^{-6}$ for any of the U.S. Population. Thus, if even a single hyperthyroid or thyroid cancer patient is affected by the implementation of this standard, the benefit/risk balance is negative. It is reasonable for EPA to make a determination similar to that made for the High Level Nuclear Waste Disposal Facilities, namely "Safe With an Ample Margin of Safety" based on the fact that the risk presented by this source sub-category $\left(<10^{-6}\right)$ is significantly lower than the $1 \times 10^{-4}$ benchmark.

EPA has attempted to demonstrate the ease with which a facility which is not exempted from the reporting requirement can show compliance. We agree that the methodology is relatively simple if, and only if every facility has access to the required computer, the required data for input to the program, release points may be aggregated, and reasonable assumptions can be made about receptor locations and locations of milk and other food supplies. Our concern is that, while current intentions are to ease the burden on the licensee, future implementation will be based on 
the lelter of the law: Those who will be required to report face the extensive requirements of 61.104. EPA has not addressed the cost of the recommended program (Alternative I) despite the fact that medical facilities could be required to spend appreciable sums to prove compliance, report annually and with every facility change, or to needlessly refine and construct complex emissions control systems.

We trust that you will carefully consider these conments in your reconsideration of the rule. If you require clarification or additional information please contact the Radiation Safety Branch at 301-496-5774.

Sincerely,

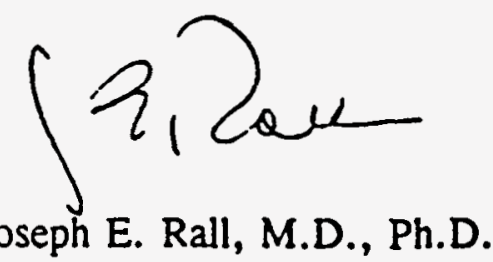

Deputy Director for Intramural Research

Office of the Director 
National Institutes of Health Bethesda. Maryland 20892 Building : 1

Room : 126

(301) 496.1921

May 11, 1989

Central Docket Section $(A-130)$

Environmental protection Agency

Attת: Docket No. A-79-11

Washington, DC 20460

Dear Sir or Ms:

This is in response to your request in the Federal Register of March 7, 1989 for written comments on the proposed amendment to 40 CFR Part 61 with emphasis on the proposed national emission standards for radionuclide emissions from non-exempted facilities licensed by the Nuclear Regulatory Commission. Enclosed is a report containing our comments on selected topics as well as a collection of comments from individuals who are experts in radiation epidemiology and radiation health effects.

The use of radioactive materials is very important to the accomplishment of the mission of NIH in that it is estimated that 70-80\% of all research at NIH is performed using these valuable tools. A comprehensive and effective Radiation Safety Program is required to meet Federal regulatory requirements and to ensure the health and safety of the public community surrounding NIF. Control measures have been taken to ensure that the exposures to the public are as low as reasonably achievable and public health is protected with an ample margin of safety. BY EPA's own estimates, exposure due to air emissions of radionuclides from a biomedical and clinical research facility such as NIH is at or below a level of 10 mrem/yr ede. We believe that existing NRC standards adequately protect the public with an ample margin of safety and it is unnecessary for EPA to promulgate another standard for NRC Iicensed facilities.

If EPA does promulgate a standard, I am concerned that NIH resources will be wasted on insignificant risks. The cost in expense and effort to implement the standard must be balanced against the gain from any possible reduced risk. Furthermore, the cost to achieve this must be balanced against any detrimental effect on health that results from the effort. It is a "given" that the biomedical research carried out at NIH is severely limited by the availability of funds and personnel. Any additional administrative burden placed on the NIH will clearly detract from our productivity in research. It is also a "given" that NIH has consistently produced results that have benefited the health of the American people. A reduction in these benefits must clearly be taken as an important factor in setting goals for airborne emissions of radionuclides. It is not at all clear that this factor has been given appropriate consideration in the proposed rulemaking. 
It is also noted that the largest radionuclide contributors to the estimated individual effective dose equivalent from NIF emissions are the radioiodines. EPA estimates that the NRC and non-DOE federal facility source category results in 0.13 fatal cancers per year. There is no discussion of the many Iives saved in the U.S. every year by the use of radioiodine therapy. The use of I-13I is currently, and will continue to be of great importance in clinical medicine since it is the treatment of choice for hyperthyroidisin and thyroid cancer, both of which are common disorders. Excessive restrictions on its use will reduce the beneficial uses of radioiodine and unnecessarily add to the escalating cost of medical care. We are urging the EPA to exempt this activity from regulation with the understanding, of course, that it is currently and appropriately regulated by the NRC.

We trust that you will carefully consider our comments when EPA decides if they will or will not regulate sources of airborne radionuclides from NRC licensed facilities. If you require clarification or additional information please contact Mr. Ted. W. Fowler or Mr. Robert A. Zoon of the Radiation Safety Branch at 301496-5774.

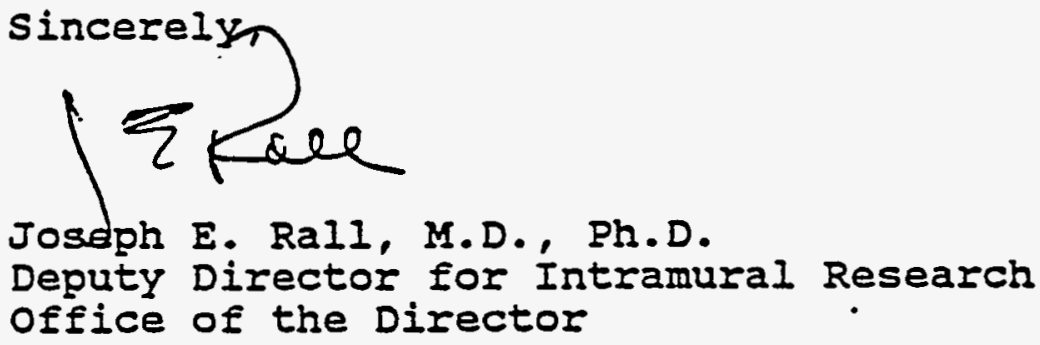

Enclosure 
Comments on the Environmental protection Agency Proposed Amendment to 40 CFR Part 61 Proposed Regulation of Radionuclide Emissions National Emission Standards for Hazardous Air Pollutants May 1989

Radiation Safety Branch Division of safety National Institutes of Health 
It is our understanding that the EPA is obligated to reexamine each source category and assure that public health is protected and EPA may find that standards are unnecessary so long as public health is protected with an ample margin of safety. We believe that existing NRC standards adequately protect the public with an ample margin of safety for biomedical and. clinical research facilities such as the NIH. NIH's comprehensive and effective Radiation Safety Program has ensured the health and safety of the public community surrounding $N I H$ as well as adequately met Federal regulatory requirements including controls to keep radiation doses as low as reasonably achievable (ALARA). EPA's own estimate of exposure due to air emissions of radionuclides from this source category is at or below a level of $10 \mathrm{mrem} / \mathrm{yr}$ ede. Under the case-by-case approach, EPA determined that 10 mrem/yr ede is the baseline acceptable level and no further reduction below the safe level is required. since the source category is already performing at a safe level, we feel that another standard is unnecessary. The standard will not enhance safety for the public, but it will result in unnecessary and expensive paperwork for the affected facilities to prepare the reports required to demonstrate compliance with the additional standard. An additional manpower cost will also be required to respond to inspections by both the NRC and the EPA. 
Level of standard

If EPA feels compelled to promulgate a NESHAP, NIH recommends that the level be higher than the proposed baseline level of 10 mrem/yr ede and that the recommendations of the National council on Radiation Protection and Measurements be adopted (reference NCRP Report No. 91, "Recommendations on Limits for Exposure to Ionizing Radiation", June 1, 1987). For public exposures to manmade sources, the NCRP recommends annual limits of 100 mrem for continuous exposures and 500 mrem for infrequent exposures. In recommending these safe levels, the NCRP believes that the recommendations are in concert with current concepts and understanding of radiation risks and their magnitude. In response to a specific need by EPA, the NCRP addressed the subject of control of multiple sources in the case of airborne radionuclides (reference NCRP Statement, "Control of Air Emissions of Radionuclides!", 1984). The NCRP commented that a regulatory agency charged with protection of the public may consider it necessary to regulate individual sources to assure that no individual receives a continuous radiation dose above the $100 \mathrm{mrem} / \mathrm{Yr}$ recommended limit. The NCRP recommended that whenever the potential exists for an individual member of the public to exceed 25 percent of the annual effective dose equivalent limit from irradiation attributable to any site, the site operator should be required to assure that the annual exposure of the maximally exposed individual from all sources would not exceed 100 mrem on a continuous basis. The EPA adopted the simplified screening model developed by the NCRP to calculate dose from emissions of radionuclides to the air (reference NCRP Commentary No. 3, "Screening Techniques for Determining Compliance with Environmental Standards", January 1989). NIF recommends that EPA also adopt the NCRP recommendations if a NESHAP is promulgated for non-DOE NRC licensed facilities. It is also noted that the proposed revision to $10 \mathrm{CFR} 20$ which should be implemented shortly states that a NRC licensee will be in compliance with the 500 mrem annual limit for individual members of the public if the licensee demonstrates that sources under the licensee's control will not result in an individual member of the public receiving a dose in excess of a 100 mrem annual reference level. 
our analyses of the dosimetric impact of individual nuclides using the COMPLY computer program indicate that the radioactive isotopes of iodine dominate the effective dose equivalent calculation. EPA states that the objective of this standard is to limit the total risk from each source category to a single fatal health effect per year (presumably due to radiation induced cancer). It does not appear that any analysis of the benefit of the activity being controlled was factored into the choice of a standard, nor was any activity specifically exempted from the standard based on established benefit.

In the United States there are approximately 10000 new cases of thyroid cancer per year. The annual mortality is 1000. The effectiveness of the use of iodine-131 in the treatment of this disease is indisputable. Indeed, many lives are saved each year by treatment of thyroid cancers using this technique. Not only is the effectiveness of the treatment an established fact; there is no alternative medical treatment which competes with the use of I-131 in this regard. The standard proposed in 40 CFR Part 61 could have a significant impact on the use of I-13I as a therapeutic agent for this disease. Therapeutic doses for thyroid carcinoma are generally large (one hundred to several hundreds of millicuries per patient treated) and, therefore, can represent a substantial fraction of the total nuclide contribution to an institutional annual effective dose equivalent (especially if institutions are "locked" in to the use of highly conservative factors in determining airborne releases, and pathway modeling which propagates conservative assumptions in the calculation of receptor dose).

The proposed standard of $10 \mathrm{mrem} /$ year ede or lower could conceivably have the effect of causing many more fatal cancer deaths than it would prevent by reducing the availability of I-131 cancer treatment due to this unnecessarily restrictive system of compliance. At a minimum, the costs associated with such treatment will escalate, perhaps substantially, depending on what measures are required to achieve and demonstrate compliance with the proposed standard.

The National Institutes of Health strongly urges that the EPA consider exempting $I-131$ used for cancer therapy from all regulation and compliance requirements within the scope of the proposed standard. Such an exemption could be justified on humanitarian grounds and substantiated with a benefit/risk analysis which clearly demonstrates the value of this activity in the preservation and extension of human life.

I-131 is also used for the treatment of hyperthyroidism. The usual treatment dose is approximately $5 \mathrm{mCi}$ and although the 
procedure does not require hospitalization, doses are typically prepared and administered in the hospital setting. Alternative definitive therapy such as surgical thyroidectomy is more costly and more dangerous to the patient. NIH does not perform many of these procedures, but it is common in general hospitals. Hyperthyroidism occurs in about two percent of the population. It may be prudent for EPA to examine the implications that this standard would have on the use of I-131 in the treatment of hyperthyroidism. 
Compliance Demonstration

Practical Issues

EPA has developed an extensive "tiered" system to determine compliance with the proposed standards. The system would appear to be designed toward simplifying the task of proving compliance for small licensees. For example, using tier 1, a facility's annual possession quantities can be employed to determine exemption from the more detailed analyses and reporting. For a facility the size of the NIH, the annual possession quantities that provide the exemption (Table 3-1 from EPA/520/1-89-002) would be exceeded.

Tier 2 would permit determination of exemption by knowledge of the actual concentrations in each stack, vent or discharge point. The requirement is that the measurements must have been made using "EPA-approved methods". There are significant technical problems that essentially render this approach impractical. First and foremost, the concentration levels for environmental compliance (Table $3-2$ ) are so low that the limits of sampling and measurement technology are approached. In particular, the compliance concentrations for radioiodines, $\mathrm{P}-32$ and $\mathrm{s}-35$ are at or beyond the state of the art in measurement technology. Even where such measurement is possible with achievable minimum detectable concentrations (MDC'S), in practice it may be required to sample the entire vent release to collect sufficient activity to reach these limits. While there are excellent commercially available systems for sampling radioiodines employing activated charcoal, we are not aware of any such "off the shelf" systems for sampling radioactive sulfur, carbon, phosphorus in an air effluent stream. In fact, such sampling is usualiy only possible using bubbler technology where the sampled air passes through a chemical reagent designed to trap the element to be sampled. such systems are impractical for the continuous monitoring of an effluent release point from a building. In addition, the initial and routine calibration and maintenance of such systems would be economically prohibitive. The point here is that tier 2 compliance will probably never be demonstrated, except perhaps in the case of a licensee with a single nuclide in a chemical form for which there is an established sampling methodology, from no more than a few release points.

Tier 3 and tier 4 are required to be used by those who cannot demonstrate compliance using the first 2 tiers. For both these tiers the detailed physical and performance characteristics of EVERY stack, vent or release point with its associated release rate for each controlled nuclide must be known. The NIH is a campus of some 400 acres, with no less than 23 individual laboratory buildings including the largest research clinical 
hospital in the world. There are over 5000 scientists and technical staff using over 33,000 individual annual shipments of radioactive research compounds in over 2200 posted controlled laboratories. The detailed data collection and reporting effort required for this facility to "demonstrate" compliance in tier 3 and/or 4 is a task of voluminous enormity and complexity. Iiterally hundreds of potential release points would need to be modeled in accordance with "A Guide for Determining Compliance with the Clean Air Act Standards for Radionuclide Emissions from NRC-Licensed and Non-DOE Federal Facilities." some allocation would have to be made of the 33,000 shipments of materials amongst these hundreds of vents, and then each one would need to be analyzed in accordance with level 3 or by using COMPIY. Due to the geographic size of NIH, multiple receptors would need to be modeled for each release point to determine the maximum receptor based on the combination of releases. This task would be difficult (and costly) enough if the data for each release point was immediately available. According to the NIH Division of Engineering Services (DES), data such as stack flow rate, stack height, stack gas temperature, etc. is only known for relatively few of the multitude of building vents on the campus. one of the DES engineers estimated a two to three year contract effort at considerable cost to attempt to accurately assess each such release point as required to complete the report.

Furthermore, this massive report of data demonstrating compliance would need to be redone each year by March 31, for submission to EPA regional headquarters, with the previous year of nuclide use data.

Certainly, each major institution with a significant number of laboratory buildings would face the same massive analysis effort annually. Every national laboratory, university, hospital center, medical facility and research institution would be subject to this requirement, with failure to do so, or errors in the report subjecting the institution and its representatives to "significant penalties ... including the possibility of fine or imprisonment."

Lest a reader interpret these criticisms by the NIH to mean that we do not take (or want to take) appropriate measures to insure that exposures from the use of radioactive materials are ALARA, it should be noted that the NIH has an established comprehensive radiation safety program with a staff of over 30 professional, technical and support staff. Regular user training, work area inspections, monitoring (restricted area, ventilation duct, and environmental), routine requirements for engineering controls in the use of volatile materials, a comprehensive bioassay program for users of radioactive materials (particularly volatile forms), and investigation of any significant internal uptake or detectable air sample ensure that local exposure from airborne 
radioactivity or discharge to the environment is absolutely minimized. We do not believe the extensive analytical exercise demanded by 40 CFR Part 61 would in any way enhance the program in its mission of reducing radiation exposure. In fact, the massive duplication of effort represented by these requirements would, in fact, significantly dilute the resources available to conduct our radiation safety program. 
Serial Hyperconservatism in Choice of Assessment Factors

When a standard is developed that is inherently conservative to start, such as 10 mrem (or less) for this rulemaking, it would seem advisable to permit facilities subject to the standard to use realistic models to determine compliance. Contrary to this approach, in the choice of every factor that affects the calculation of compliance, a conservative choice has been made. This is particularly significant for the choice of fraction of liquids that become airborne (i.e. "emission factor" $=0.001$ ) and the "adjustment factor" for activated charcoal treatment of radioiodines (allowed at 0.1 ). While the emission factor specified may be appropriate for known volatile compounds of H-3 or iodine isotopes, we do not believe that it could be defended for elements which have no known volatile or gaseous compounds. This factor should be reevaluated and reduced where appropriate. The Background Document "Procedures Approved for Demonstrating Compliance with 40 CFR Part 61, subpart I" admits that "the efficiency of a freshly mounted carbon filter frequently exceeds 99 percent.." It then goes on to say that "..the removal efficiency may drop to as 10 as 90 percent prior to cartridge replacement." There are two issues to note here. First, 90 percent is the anticipated minimum efficiency of such a system. Why choose this lowest performance as the value for the adjustment factor? Why not an average expected over the useful life of a filter, or the minimum efficiency based on Good Engineering Practices (GEP) for filter replacement? The second issue is the matter of application of this factor. In many exhaust systems at NIH where volatile iodine is possible during an experiment, the experiment is treated locally via an activated charcoal filtered containment box and emissions from the local box are subsequently treated by an in-line activated charcoal filter system in the ventilation duct. Is it permitted to take credit for the "adjustment" factor for each of these systems serially (i.e. a total adjustment of 1E-06)? Clarification of this matter is required. This is an extremely important issue; our analysis of the nuclide by nuclide impact of the compliance demonstration procedures shows that radioactive isotopes of iodine are the major contributors to the calculated effective dose equivalent for a biomedical research facility like the NIH.

Further "serial" conservatism is applied in the pathway analysis for the effective dose equivalent (ede) due to iodines. The nearest receptor is assumed to grow all their vegetables at home, get all their milk from the nearest cow and all their meat from the nearest farm. This is unlikely even in a rural setting, but certainly ludicrous in an urban setting. The use of conservative assumption upon conservative assumption which propagate in the calculational procedures for implementation of compliance for a very conservative standard is totally unwarranted. 


\section{Estimate of the costs of Demonstrating Compliance}

While it is difficult to quantify costs associated with an activity which is not currently being conducted, we believe that some estimate would be of value in assessing the economic effect of this standard. In the first year of compliance verification, the costs would be substantial for a facility as large as the NIH. It has already been stated that to measure the physical characteristics of building vents and stacks to literaliy follow the compliance reporting procedures of tier 3 or 4 , a major contract effort would be required. considering the cost of contracting, along with associated procurement, management, etc. such a contract could cost as much as $\$ 500,000$. Estimating that there would be between 100 and 200 release points to be characterized and modeled with a population of $6-12$ receptors, we estimate initial analysis and reporting would involve a work effort of two professional labor-years. A major part of the initial analysis would be the development of a computer model which permits the construction of a reporting "template" to allow efficient repeat reporting annualiy. An interface between the database system that records materials receipts and the system of reporting to EPA would need to be developed, linking the materials distributed to the NIH investigator community to the release points associated with their use. our database application is maintained by a consultant, with major would probably add another $\$ 20,000$ to the initial reporting effort cost. Subsequent years of reporting would be much less costly, involving perhaps $1-2$ labor-months as an upper limit. The report of "all information required in an application to construct or modify a facility ... for all construction and modifications which were completed in a relevant calendar year..." is another matter. Depending on the detail required in such a report (which has not been specified), the cost of this submission could be substantial $(\$ 100,000+)$ in each calendar year, particularly since the NIH is currently in a program of major renovation of many laboratory facilities.

Depending on whether the facility is in or out of compliance with the standards, treatment systems may need to be installed, particularly for the treatment of radioiodines. For each ventilation duct with an airflow of 1000+ CFM, an individual commercially available nuclear-grade bag-in bag-out housing fitted with appropriate pre-filters and activated carbon adsorbers would cost $\$ 5,000-\$ 10,000+100 \%$ for mechanical design and installation. Annual maintenance and certification of each such unit will cost $\$ 1000^{\circ}-\$ 2000$. 
APPENDIX 4 


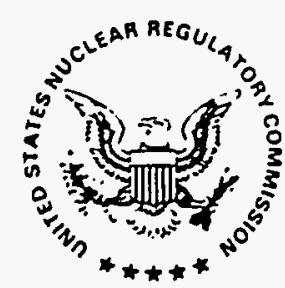

UNITED STATES

NUCLEAR REGULATORY COMMISSION

WASHINGTON, D.C. 20555

November 14, 1989

CHAIRMAN

The Honorable John D. Dingell, Chairman

Committee on Énergy and Commerce

United States House of Representatives

Washington, DC 20515

Dear Mr. Chairman:

The purpose of this letter is to share with you the Nuclear Regulatory Commission's (NRC) concerns about the duplicative regulatory scheme for emissions of radionuclides contained in the current clean Air Act and to urge you, as the Congress moves forward with reauthorization of this legislation, to address this most serious problem by eliminating the duplicative regulatory regime for such emissions from facilities that are already regulated by the NRC.

By way of background, when the Clean Air Act was last reauthorized in 1977, the Environmental Protection Agency (EPA) was granted the authority to regulate radionuclide emissions from a variety of different sources, including emissions from

facilities already regulated by the NRC. This authority, which was adopted without any Congressional hearings and without the opportunity for affected agencies to provide comments, has proven to be wholly unnecessary from a health and safety perspective, in view of the comprehensive NRC regulatory program already in place for radionuclide emissions. Additionally, this duplicative regulatory authority will, if implemented, lead to two separate regulatory regimes, one established by the NRC and one established by EPA, with the attendant costs and burdens -- both for the government and the affected private sector -- that invariably result when two agencies are charged with regulating the same activity.

Under the Atomic Energy Act, the NRC has an established and comprehensive regulatory program that regulates emissions of radionuclides in air and water from all facilities licensed by the commission. These NRC-regulated facilities include over 100 operating nuclear power plants, uranium mills, major universities, and thousands of nuclear medicine departments in hospitals nationwide. The result of this comprehensive regulatory scheme has been to keep public exposure and public risk to minuscule levels. By EPA's own calculations, the total number of potential health effects attributable to air emissions of radionuclides from all NRC licensees combined is less than 0.33 fatalities per year. For this reason, as EPA itself has acknowledged, duplicative EPA regulation in the face of NRC's 
regulatory program is "hard to defend from any logical or policy perspective." Indeed, as EPA indicated in prior comments on this issue, "existing emissions from these sources are already so low that the public health is aiready protected with an ample margin of safety . . ." 50 Federal Register 5190, 5191 (February 6, 1985). On this point, we couldn't agree more strongly with the position that EPA expressed.

Despite this lack of need for additional regulation of NRClicensed facilities, EPA has advised us that they feel constrained by existing law to issue standards for such facilities and, accordingly, on October 31, 1989, EPA promulgated regulations for radionuclide emissions from such facilities. Unfortunately, the result of this action will be a duplicative regulatory scheme that is unnecessary from any public health standpoint, wasteful of public and private resources, and even potentially harmful to public health. In the latter regard, the National Institutes of Health (NIH) advised EPA that these regulations would interfere with radioiodine treatment of thyroid patients, as well as divert resources from patient care and research, and thus could cause more deaths than they prevented. similar comments were filed by representatives of the nuclear medicine community.

It is also evident that compliance with this additional set of EPA regulations will lead to the unnecessary expenditure of resources by EPA, NRC, its Agreement States and its Iicensees. In its final rule, EPA acknowledged the seriousness of the concerns raised about the possible effects of duplicative, and perhaps conflicting, standards on NRC-Iicensees. In particular, EPA noted that:

"While the level of health protection achieved under the NRC standard is generaliy comparable to that required by EPA's rule, the two standards are very different in form, and the means of demonstrating compliance with each standard impose significantly different regulatory requirements."

In short, EPA's regulations will substantially increase the burden of demonstrating compliance with federal regulations, with no attendant additional protection for the public health and safety, thereby diverting limited resources from other more important safety concerns.

For the foregoing reasons, we urge you in the strongest terms to address this problem. The current congressional reexamination of the Clean Air Act offers an ideal opportunity to resolve the problem of dual jurisdiction and duplicative regulation by giving exclusive authority over radionuclide emissions from NRC-Iicensed facilities and activities to NRC. Duplicative regulation is inherently unsound as a matter of public policy and good 
government. In a time of limited governmental resources, public funds should not be wasted on parallel programs in two sister agencies for the same activity, especially when no additional protection for public health and safety results. A regulatory scheme such as this will impose significant unnecessary_burdens on licensees, require the expenditure of additional federal resources to assess and enforce compliance, result in unnecessary additional costs to consumers, and interfere with proper medical treatment for patients of some medical licensees.

The Commission cannot emphasize too strongly that the current NRC regulatory program provides adequate protection against radionuclide emissions from NRC-regulated facilities with an ample margin of safety. Additional regulation of these facilities by EPA under the Clean Air Act will provide no further protection of the public health and safety. The congress now has an excellent opportunity to remedy this unfortunate situation by eliminating duplicative regulation under the clean Air Act. The commission strongly urges you to do so.

\section{sincerely,}

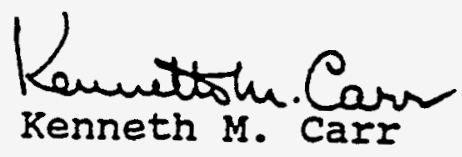

cc: The Honorable Norman $F$. Lent

William K. Reilly, Administrator, EPA

James B. Mason, M.D., Assistant Secretary for Health, HHS 


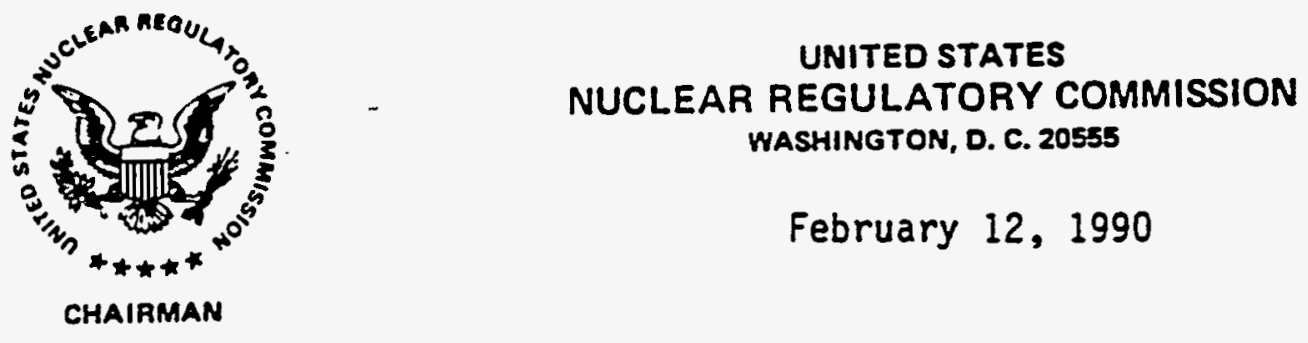

The Honorable William K. Reilly

Administrator

U. S. Environmental Protection Agency

Washington, D. C. $20460 \ldots$

Dear Mr. Reilly:

I am writing to provide the comments of the Nuclear Regulatory Commission (NRC) on Subpart I of 40 CFR Part 61, the Environmental Protection Agency's (EPA's) recently-promulgated National Emission Standard for Radionuclides under the Clean Air Act. Our comments are provided in response to the notice of reconsideration published in the Federal Register on December 15, 1989 , in which EPA announced its intent to reconsider the standards in Subpart I based on the adverse impacts associated with EPA regulation of radionuclide air emissions from NRC- and Agreement State-licensed facilities. In accordance with section $307(d)(7)(B)$, NRC also requests that EPA reconsider the standards in Subparts $T$ and $W$ of 40 CFR Part 61, which were also noticed in final form on December 15, 1989 (54 FR 51654). As you know, NRC strongly believes that dual regulation of NRC-licensed facilities, as would be provided in all three subparts, is unnecessary from any health and safety or environmental standpoint and is undesirable as a matter of policy.

With respect to Subpart I of EPA's regulation, NRC is fully in agreement with the views already expressed by EPA and the Department of Health and Human Services (HHS) in your joint letter to Congress of November 15, 1989:

Further, the Administration was advised by many facilities currently regulated by the NRC, including research and testing reactors, medical facilities, and the National Institutes of Health that regulatory schemes that involve unnecessary duplication of compliance and implementation needlessly raise costs and divert resource from needed research and other activities. This could adversely affect patient care at some facilities. . . Therefore, we believe that the pending revisions to the Clean Air Act should contain a provision to elimininate unnecessary and duplicative authority to regulate radionuclide emissions from NRC-licensed facilities.

For these and other reasons, we believe that Subpart I of the final rule would confer no additional benefits to public health and safety beyond those presently achieved under NRC regulations, but rather would impose unnecessary burdens on hospitals, research facilities, nuclear utilities, and other facilities, with attendant costs that would be passed on to patients and consumers. In the case of hospitals, as EPA and HHS noted in the joint letter, the 1 imitations could even ". . adversely affect patient care at some facilities." Our more detailed comments on Subpart I are set forth in Enclosure 1 to this letter. 
With respect to Subparts $T$ and $W$, our request for reconsideration of these Subparts is based on a number of specific implementation problems and uncertainties as well as our more general concerns with regard to unnecessary dual regulation. We note, for example, that in proposing the four complex aiternatives in the proposed rule, EPA focused attention on its approach to establishing standards rather than problems and possible impacts associated with specific implementation details. Furthermore, the final rule contains substantive provisions not found in the proposed rule. Therefore, it was impracticable for NRC to raise such objections during the public comment period for the standards in Subparts $T$ and $H$. Enclosure 2 summarizes the implementation and dual regulation problems that we see with Subparts $T$ and $W$.

We emphasize that the regulatory scheme already established under the Uranium Mill Tailings Radiation Control Act, including EPA's standards in 40 CFR Part 192, is of central relevance to the standards in Subparts $T$ and $W$ because the scheme duplicates and, in some cases, may preclude implementation of the standards. Indeed, in view of the comprehensive regulatory program already in place for uranium mill tailings, we believe that EPA should defer to this existing regulatory scheme rather than impose additional and unnecessary requirements such as those contained in Subparts $T$ and $W$.

Moreover, the same considerations that argue for legislation to eliminate duplicative regulation under the Clean Air Act argue with equal strength for EPA to exercise all presently existing authority to minimize duplication to the extent that the law allows. Although we agree that a legislative solution is the most desirable course of action given the legal controversy that attended EPA's efforts to resist dual regulation in the early 1980's, we believe that EPA has considerable latitude, even under current law, to minimize duplication.

In our view, EPA would be fully within its legal authority if it were to provide, on reconsideration of Subparts $I, T$, and $H$, that no emission standards are necessary for NRC- and Agreement State-licensed facilities in view of the fact that existing regulation already protects public health and safety with an "ample margin of safety." Indeed, we note that with regard to certain classes of facilities, including high-level waste repositories and coal-fired boilers. EPA has acknowledged that nothing in the D.C. Circuit Court's vinyl chloride decision, NRDC V. EPA, 824 F.2d 1146 (1987), requires EPA to issue emission standards where an ample margin of safety already exists. This was the very point that we made in our comments of May 15, 1989, and which we reiterate once again here.

Finally, should EPA decide to proceed with Subparts I, $T$, and $W$, we would be obliged to reevaluate NRC's role in implementation and enforcement of these standards as provided for in the Memorandum of Understanding between our agencies. Consistent with EPA's own findings, we see absolutely no incremental health and safety benefit to proceeding with these regulations and, accordingly, are not in a position to commit our limited resources and personnel to their implementation. 
We welcome EPA's recognition that existing NRC regulation provides fully adequate protection of the public health and safety and, for this reason, will continue to press our mutual call for Congress to eliminate duplicative regulation. In the meantime, we strongly urge you to exercise to the fullest extent your present authority to minimize duplicative regulation by revoking the new radionuclide emission standards for NRC- and Agreement State-licensed facilities contained in Subparts I, T, and $W$.

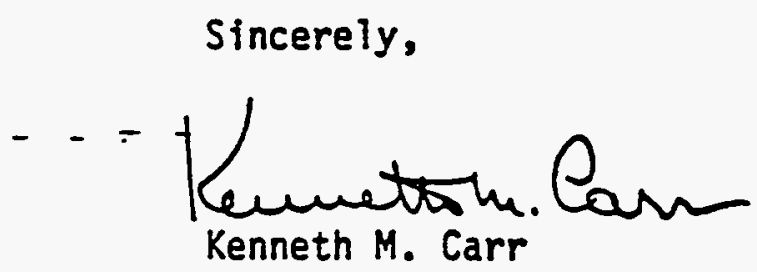

Enclosures:

1. Comments on the 40 CFR Part 61 Subpart I Rulemaking

2. Comments on the 40 CFR Part 61, Subparts $T$ and $W$ Rulemaking.

cc: Central Docket (A-130)

Environmental Protection Agency

Attn: Docket No. A-79-11 
Enclosure 1

NRC COMMENTS ON SUBPART I OF 40 CFR PART 61

IN RESPONSE TO EPA'S NOTICE OF RECOMMENDATION

1. The EPA assertion that most Nuclear Regulatory Cormission (NRC) licensees will be able to use the simple screening levels to demonstrate compliance with the NESHAP in Subpart I appears to be incorrect. The final standard will present fundamental problems for many non-fuel cycle licensees, such as manufacturers who currently have radionuclide possession limits in non-sealed source form that exceed the Environmental Protection Agency (EPA) annual possession quantities in Table 1 of Appendix $E$. (Licensees who possess less than the Table 1 quantities per year are deemed in compliance.) The estimated number of commercial facilities subject to this rule approaches 15,000 when Agreement State licensees are included. NRC licensees may request several hundred license amendments simply to lower or change the authorized possession limits in order to provide a clear means of demonstrating compliance with the EPA standards. Currently, NRC does not routinely impose annual possession limits on licensees. Although the $10-\mathrm{milli}$ irem/year committed effective dose equivalent (EDE) limit is considered an achievable limit for most types of facilities, many of NRC's materials licensees do not have the necessary environmental monitoring nor analytical capability to demonstrate compliance. Many licensees will have to use the most complicated level of the COMPLY code (level 4) because the initial levels use unrealistically conservative assumptions that severely overestimate doses.

2. In the case of medical and hospital licensees, the National Emission Standards for Hazardous Air Pollutants (NESHAPs) could cause considerable difficulties for hospitals that maintain on-going programs to investigate new uses of radiopharmaceuticals for improved medical techniques. The restrictions on yearly possession limits to qualify for simple demonstrations of compliance could encourage licensees to eliminate such programs and result in reduced health care simply to avoid the problems and cost associated with demonstrating compliance.

3. A major potential impact on the programs of NRC, Agreement States, and all categories of 1 icensees is compliance with the facility construction and modification requirements of Subpart $A$ of 40 CFR Part 61. (Compliance with Subpart $A$ is required of ail facilities subject to all new NESHAPS, as they are issued, unless specificaliy exempted.) EPA has provided a threshold dose increment of $0.1 \mathrm{mill} / \mathrm{rem} /$ year for requiring advance EPA approval of construction or modification, provided the facility is in compliance with Subpart I and performs and retains an evaluation to demonstrate that the incremental impact is less than the $0.1-m i 11$ irem/year threshold. This is an extremely small increment and may be of little 
value in view of the uncertainties in estimating doses at this level and the penalties associated with noncompliance under the Clean Air Act. Facilities such as hospitals and universities may have to request numerous and frequent EPA approvais of modifications to release points because of the number and diversity of buildings, ventilation-release points, incinerator stacks, and fume-hood exhausts associated with the use of radioactive materials at these facilities. In addition, areas such as ore-storage pads and process pends are part of the facilities, so that licensees, such as rare-earth processors, may have to obtain EPA approval of construction or modifications associated with these parts of their operations as well. Hundreds of licensees may have to file applications, beginning on the effective date of the rule. NRC and Agreement States may have to review applications for license amendments to accommodate the EPA permitting process and inspect the modifications to, or new construction of, facilities precipitated by EPA's new standards. Even if NRC or State licensing amendments are not required, additional review and inspection resources may be needed to assess changes in facilities or operating procedures and confirm continued compliance with NRC and Agreement State requirements.

4. Although currently operating licensed uranium conversion plants and uranium processing and fabrication facilities can meet the 10-millirem/ year EDE limit, it is not realistic to expect that these licensees will be able to demonstrate compliance using the January 1989 version of the COMPLY code. To establish compliance with 40 CFR Part 190, these licensees were required to install and operate continuous air-monitoring stations at nearby sites where members of the public are located and to undertake extensive and costly analyses of the samples obtained. This was done in part because of the large uncertainties in dispersion modeling and to enable more accurate dosimetry. Under the new NESHAP for radionuciides in Subpart I, in many cases it will be necessary for licensees to rely on alternate compliance models that use additional or different data and assumptions. Case-by-case approvals of such alternate models will pose additional burdens on both the licensees and the implementing regulatory agencies, thus diverting resources from activities of greater health and safety benefit.

5. The applicability of the standard to temporary work sites and outdoor sites is unclear. Section 61.100 states that the standard applies only to icensed facilities, and 61.101 defines facility as "all buildings, structures, and operations on one contiguous site." In many cases, however, licensed material is authorized for use at temporary and outdoor job sites. In outdoor tracer studies, for example, liquid radioactive material is released to a well to determine hydrogeologic characteristics. These types of activities cause airborne emissions, as the tracers containing the radioisotope are allowed to evaporate or disperse into the atmosphere. Because there is no specific release point at which to measure the concentration of the radionuclide, it is unclear how a 
licensee is to determine if these activities are in compliance with the emission standard. Furthermore, there are no criteria in the January 1989 COMPLY code which allow for these types of licensees to demonstrate compliance.

6. NRC endorses EPA's attempt to maintain consistency with NRC's existing regulatory program by referencing several Regulatory Guides. The standard, however, incorperates dated versions of several NRC Regulatory Guides directly into the implementation section of the rule, thereby limiting the licensee's use to those versions of the Guides and not allowing use of revised Guides without additional rulemaking by EPA. Furthermore, Regulatory Guides, as used by NRC, are not intended as requirements but rather as one acceptable approach for demonstrating compliance with NRC requirements. Therefore, it is inappropriate for EPA to incorporate them by reference in EPA regulations.

7. Subpart I provides for dual regulation by NRC or Agreement States and EPA of both operating and closed low-level waste sites. The EPA-required compliance procedures are not sufficiently clear to estimate emissions from waste packages and disposed waste with confidence. (Use of the computer code package CAP-88 is mentioned in the preamble, but not described or referenced in the rule. NRC is not familiar with this package of codes.) Although site-specific alternatives to the COMPLY code have been included, only site-specific implementation will determine whether the standard will cause significant problems in demonstrating compliance. Such regulatory uncertainties are also potentially disruptive to development of new disposal facilities by January 1, 1993, in accordance with the Low-Level Radioactive Waste Policy Amendments Act of 1985. These facilities are needed to minimize reliance on indefinite storage of wastes in temporary facilities.

8. The significance of the differences in the exposure limits in Subpart I and existing standards have not been determined for low-level waste sites and uranium mills. Current limits for new low-level waste sites are contained in NRC's regulations in 10 CFR Part 61 . Limits for exposures, other than those from radon, for the uranium fuel cycle, including uranium mill facilities, are contained in 40 CFR Part 190. In both cases, the annual dose limits are 25 millirem to the whole body, 75 millirem to the thyroid, and 25 millirem to other organs. The new Subpart I would establish an annual effective dose equivalent (EDE) 1 imit of 10 millirem, of which only 3 millirem can be from iodine. Although EPA concluded that the 1 imits in Subpart I and 10 Part 61 and 40 CFR Part 190 are essentially equivalent, the practical implications and significance of the differences between the standards have yet to be determined. The significance will be better understood once the new International Commission on Radiological Protection (ICRP) methods are applied to radionuclides of interest at uranium mills and low-level waste sites, and EPA's final implementation documents and computer codes are examined. Using the January 1989 
compliance documents, operating mills would likely not be able to comply with the dose limits of Subpart I because of the conservative assumptions used in the COMPLY code. Regulatory agencies and licensees will have to deal with two procedures for determining doses without any apparent practical benefit in risk reduction.

9. The implementation of EPA's standard requires a continual awareness by NRC licensees of locations_of the maximally exposed individual from Inhalation, immersion, and ingestion pathways. For power and research/ test reactors, industrial and heal th care facilities, and other non-reactor licensees, this requirement constitutes a moving target uniess compliance is conservatively demonstrated at the facility boundary. Power reactor personnel currently maintain an awareness of receptor locations in each sector in the vicinity of the plant and are thus somewhat accustomed to living with such moving targets. Research and test reactor personnel, on the other hand, do not typically maintain an awareness of distances to receptor locations in each sector; such a requirement would potentially pose a new burden on non-fuel cycle licensees to maintain an awareness of transient receptor locations.

10. Section 61.103 requires the use of the EPA COMPLY code to determine whether the Timits of Section 61.102 have been met. Certain alternative methods are allowed. Neither the COMPLY code nor the cited alternative methods are currentiy in use by NRC licensees. For example, if power reactor 7 icensees were to switch to EPA-mandated codes and revise their Offsite Dose Calculation Manuals (ODCMs) accordingly, the ODCM changes would need to be reviewed to ensure that NRC requirements continued to be met. Licensees could, however, maintain a dual system, using both their current NRC-reviewed ODCM methodology as well as EPA's new methodology. Even this, however, would require that NRC staff be somewhat familiar with the above-mentioned EPA code/methods to be able to understand certain licensee actions which may derive from their use. In addition, maintenance and use of two separate methodologies and procedures for off-site dose calculations could cause avoidable confusion for licensees, regulatory agencies, and the public.

11. Nuclear power reactor licensees have been required for many years by 10 CFR Subsection 50.36a to report effiuent releases semi-annually to NRC. Subsection 61.104(a) requires annual reports of effiuent releases to EPA, plus additional details on emissions that do not seem relevant to an ongoing demonstration of compliance. Facilities not in compliance with 40 CFR Section 61.102 are required to report to EPA on a monthly frequency. NRC requires power reactor licensees to submit similar reports via 10 CFR Part 50, Appendix I. Such duality of reporting appears to have no benefit. Consistent with the Paperwork Reduction Act (44 USC $3510(a)$ ). Federal agencies should cooperate with each other and share reports to reduce the burdens on the regulated community. Since emission reports are al ready required by NRC, EPA should not impose new reporting and data collection requirements. EPA should rely on the existing regulatory framework. 
12. Section 61.107 requires emissions monitoring at all release points having the potential to exceed 1 percent of the Section 61.102 limits. Since "potential" could refer to any situation with a non-zero probability, there are many points at facilities such as nuclear power plants or large processing facilities that could meet this broad criterion. These monitoring activities and associated record-keeping would pose a significant additional burden on licensees and on NRC and Agreement States, who would review these-additional monitoring data during inspections.

13. Subsection $61.107(c)(1)$ allows nuclear power plants to determine emissions of radioactive materials in conformance with Effluent Technical Specifications. NRC's Technical Specification Improvement Program, through Generic Letter $89-01$, is allowing licensees to place these specifications into licensee-controlled documents, rather than in Technical Specifications, to reduce administrative burden on both NRC and the licensees. Therefore, the provision in Subsection $61.107(\mathrm{c})(1)$, by referencing only Technical Specifications, may not be available to many 1 icensees.

14. Based on the discussion in the proposed and final rule notices, EPA may not have given due weight to the potential inequity created by listing and establishing standards for radionuclides as a single pollutant. NESHAPs for chemical pollutants have been developed for specific elements or compounds with no comparable restriction on the risk to the public from the total exposure to all nonradiological pollutants.

NRC agreed with the listing of radionuclides as a single pollutant in the eariy 1980's. It should be noted, however, that use of this collective approach for limiting radionuclide emissions may result in more stringent risk levels for radiological pollutants. Certainly it is reasonable to conclude that higher total risks accrue to the public from facilities which release maximally allowed quantities of more than one pollutant listed under the NESHAPs on a chemical-by-chemical basis than from facilities that emit a single pollutant.

This additional conservatism inherent in the collective approach for radionuclides provides additional support for EPA to conclude that the existing NRC and Agreement State regulatory frameworks already provide an equivalent level of protection to that envisioned under EPA's new rule. 
Enclosure?

NRC COMMENTS ON SUBPARTS T AND W OF

40 CFR 61 IN SUPPORT OF A. PETITION FOR RECONSIDERATION TO EPA

The Nuclear Regulatory Commission petitions EPA to reconsider the final standards in Subparts $T$ and $W$ of 40 CFR Part 61 because it was impracticable to raise objections to EPA's standards in these subparts before they were promulgated and because these objections are of central relevance to the outcome of the standards. EPA's final standards in Subparts $T$ and $W$ of 40 CFR Part 61 were issued on October 31, 1989, and noticed in the Federal Register on December 15, 1989, at 54 FR 51654. The final rule contains substantive provisions not found in the proposed rule that was noticed in the Federal Register on March 7, 1989, at 54 FR 9612. Therefore, it was impracticable for NRC to raise such objections during the public comment period.

NRC's comments are of central relevance to the standards in Subparts $T$ and $W$ because they illustrate how the comprehensive regulatory scheme al ready established under the Uranium Mill Tailings Radiation Control Act duplicates and, in some cases, may preclude implementation of EPA's new standards in Subparts $T$ and $W$ of 40 CFR Part 61 . The standards are of significant interest to NRC and Agreement States because they will require the agencies to spend resources to review and approve activities that are already adequately regulated under the comprehensive regulatory scheme. Therefore, under Section $307(d)(7)(B)$ of the Clean Air Act, NRC petitions EPA to reconsider the standards in Subparts $T$ and $W$ based on the comments provided below.

Subpart T: Radon Emissions Standards for Disposal of Uranium Mill Tailings

1. Many sites will not be able to comply with the two-year deadline to stabilize the mill tailings because of physical and legislative constraints. The final standard in 40 CFR 61.222 requires that uranium mill tailings impoundments be closed within two years after the effective date of the standards or after cessation of operations, whichever is later. Most licensees at active mills under Title II of UMTRCA will not be able to comply with this deadline because the tailings will not be sufficiently dry and stable to allow placement of earthen covers to reduce radon emissions and ensure long-term stability. In addition, DOE may not be able to comply with the deadline because remedial action at the inactive tallings sites under Title I of UMTRCA is proceeding according to a Congressionaliy-approved schedule for completion in 1994, subject to the adequacy of Federal appropriations. Consequentiy, EPA will need to negotiate compliance agreements with licensees and DOE to establish al ternate schedules for compliance. The negotiations will also need to include NRC and Agreement States as responsible regulatory agencies for the active uranium mills and as concurring agencies for the remedial actions. This complex regulatory process is unnecessarity burdensome 
because the licensees and DOE are already in the process of stabilizing the uranium mill tailings and existing regulations are fully adequate to ensure protection of human health and the environment. In addition, the compliance negotiations could also impede and delay some remedial and reclamation activities because of EPA's requirement for pre-approval of cover designs and the duplicative, but not necessarily consistent, regulatory framework established by the standards in Subpart $T$.

2. The final standards in Subpart $\bar{T}$ generally duplicate existing EPA and NRC requirements under the Uranium MilT Tailings Radiation Control Act (UMTRCA) for uranium mill tailings disposal sites. The standards do not provide an exemption for filing applications under subpart $A$ of 40 CFR Part 61 for facility construction and modifications. Consequently, the Department of Energy (DOE) and uranium mill licensees will have to obtain prior approval by EPA for all cover designs and modifications. As a result of the duplicative nature of EPA's Subpart $T$ standards with NRC and EPA standards already in place, both EPA and NRC will have to review and approve the same designs and design modifications, thus doubling the administrative resources necessary to ensure that covers for uranium mill tailings are adequately designed and constructed. In addition, it is unclear whether designs that are in process or under construction also require EPA's prior approval. Such a requirement would delay and disrupt current stabilization efforts by licensees and DOE. The delay and disruption is not justified given that EPA's standards in Subpart $T$ do not enhance protection of the public and the environment beyond that attained under the current regulatory framework. In fact, they may actually result in decreased protection by slowing down or stopping work already in progress to stabilize the tailings.

3. EPA's final standards in Subpart $T$ may restrict the flexibility to approve site-specific alternatives in accordance with UMTRCA and the Atomic Energy Act. The final standards reference specific subparagraphs of EPA's

standards in 40 CFR Part 192. However, they do not explicitly provide for site-specific alternatives to the referenced standards that are provided for in Section 84c of the Atomic Energy Act or in Subpart C of EPA's standards in 40 CFR Part 192. NRC's authority to approve such al ternatives for Title II sites was upheld last year by the Tenth Circuit Court of Appeals (EDF V. NRC, 866 F.2d 1269(1989)). Agreement States may also approve such alternatives provided that NRC concurs. Similarly, EPA's standards in Subpart C of 40 CFR Part 192 provide for supplemental standards in lieu of the primary standards in Subparts $A$ and $B$ for Title I sites. Therefore, it appears that EPA's standards in Subpart $T$ of 40 CFR Part 61 under the Clean Air Act conflict with EPA's standards in 40 CFR 192 under UMTRCA, as well as the Atomic Energy Act itself, in that they may limit the flexibility provided earlier by Congress and EPA. 
Subpart H: Radon Emissions Standards for Operating Uranium Mill Tailings

4. EPA standards in Subpart $W$ require the NRC to do something that NRC does not have the authority to do under the Atomic Energy Act. The standards in 40 CFR 61.252(b) require operation of uranium mill tailings impoundments in accordance with the requirements of 40 CFR 192.32 (a) as determined by the NRC. In Agreement States under Section 274 of the Atomic Energy Act, the States regulate uranium mills in lieu of Federal regulation by NRC. Thus, the Agreement States should determine that impoundments are operated in accordance with 40 CFR 192.32(a). However, EPA did not include a provision for determinations by Agreement States or define NRC to include Agreement States, as it did in Subpart I of 40 CFR Part 6I. Therefore, EPA's standards in Subpart $W$ require NRC to make a determination in Agreement $S$ tates that NRC does not have the authority to make. The lack of such NRC authority has rio practical impact on safety, however; NRC already requires Agreement States to implement measures to assure that tailings piles comply with EPA's 40 CFR Part 192 requirements, and monitors that implementation through its reviews of Agreement State programs.

5. EPA's final standards under Subparts $W$ and $A$ of the 40 CFR Part 61 duplicate aspects of EPA's and NRC's existing regulatory requirements and framework for management of active uranium mill tailings sites. Under Subpart A, uranium mill licensees will have to seek prior review and approval by EPA of the design, construction, and modification of uranium mill tailings impoundments. NRC already has a comprehensive regulatory program for uranium mills, including design and environmental reviews, licensing of the mill facilities and impoundments, and inspection of the construction, operation, and closure of the facilities and impoundments. Thus, EPA's new standards in Subparts $W$ and $A$ duplicate a portion of NRC's comprehensive framework, which implements EPA's requirements in 40 CFR Part 192. The additional administrative and economic burden on licensees and NRC is not justified because EPA's standards in 40 CFR Part 61 do not provide any significant incremental enhancement in the protection of the public and the environment beyond that achieved under the current regulatory framework.

6. EPA's final standards in Subpart $W$ may restrict the flexibility to approve site-specific alternatives in accordance with UMTRCA and the Atomic Energy Act. The standards in 40 CFR 61.252 specifically reference subparagraph 192.32(a) in EPA's standards in 40 CFR Part 192. However, they do not explicitly provide for site-specific alternatives to the referenced standards that achieve a level of protection equivalent to, to the extent practicable, or more stringent than, NRC's requirements in 10 CFR Part 40 and EPA's requirements in 40 CFR Part 192 in accordance with Section 84C of the Atomic Energy Act. NRC's authority to approve such alternatives for Title II sites was upheld last year by the Tenth Circuit court of Appeals (EDF V. NRC, 866 F.2d 1269 (1989)). Agreement States may also 
approve such alternatives provided that NRC concurs. Therefore, it appears that EPA's standards in Subpart $W$ of 40 CFR Part 61 under the Clean Air Act conflict with NRC's requirements in 10 CFR Part 40 under UMTRCA, as well as the Atomic Energy Act itself, in that they may limit the flexibility provided earlier by Congress to allow site-specific alternatives to NRC's and EPA's requirements.

7. EPA's standards in Subpart $W$ are unclear on whether EPA intends to duplicate NRC's site-specific implementation responsibilities under UMTRCA and the Atomic Energy Act. The final standard in 40 CFR $61.252(\mathrm{c})$ requires that licensees operate uranium mill tailings piles in accordance with EPA's requirements in 40 CFR 192.32(a). However, EPA has not specifically provided for a determination by NRC or Agreement States that pile operations comply with 192.32(a). Thus, the standard is ambiguous on whether NRC and Agreement States determine compliance (consistent with the "regulatory agency" concept in 192.31(g)) or whether EPA has provided for itself a site-specific regulatory role for groundwater protection. The standards referenced in 192.32(a) are the primary standards for design, operation, and groundwater protection for active uranium mill tailings impoundments; they have been incorporated into NRC's conforming requirements in 10 CFR Part 40, Appendix A, and are actively being implemented and enforced by NRC and Agreement States. EPA implementation and enforcement of these standards would unnecessarily duplicate the comprehensive regulatory programs for uranium mill tailings management that have already been established by NRC and Agreement States. In addition, such duplication could result in implementation and enforcement actions that are inconsistent with NRC and State actions under identical requirements, which could actually impair current efforts to protect the public and the environment from hazards associated with uranium mill tailings at active sites. 
APPENDIX 5 


\section{Nov 15}

Honorable Quentin N. Burdick

Chairman, Committee on

Environment and Public Works

United States Senate

Washington, D.C. 20510

Tear Mr. Chairman:

On October 31, 1989, EPA promulgated a standard for radionuclide emissions under section 112 of the clean Air Act (CAA), as required under a decision of the U.S. Court of Appeals for the District of Columbia.

In the rule EPA established a benchmark of approximately $1 \times 10^{-4}$ for defining acceptable lifetime risk of fatal cancer. For several categories in the radionuclide rulemakings, maximum individual risks of 2 or $3 \times 10^{-4}$ were found acceptable in light of all of the circumstances of the particular cases, including small population exposures and uncertainty in risk estimates.

Legislation has been introduced regarding air toxics regulation that would establish a rigid requirement of $1 \times 10^{-6}$ or $1 \times 10^{-6}$. We would like to share with you the unintended consequences that would result from such an inflexible policy.

If EPA has been forced to use a bright line of $1 \times 10^{-4}$ or $1 \times 10^{-6}$ in its recent rulemaking concerning radionuclide emissions from NRC-licensed facilities (including hospitals and university laboratories which administer radioactive medical isotopes) $1_{6}$ at $1 \times 10^{-4}$ the EPA standard would be $3 \mathrm{mrem} / \mathrm{Yr}$, and at $1 \times 10^{-6}$ the EPA standard would be $0.03 \mathrm{mrem} / \mathrm{Yr}$. (The standard was actualiy set at $10 \mathrm{mrem} / \mathrm{yr}$.) If these standards were set, particularly the $1 \times 10^{-6}$ level, the National $\because$, Institutes of Health has stated that many larger facilities would be forced to close their radioiodine treatment facilities. Since ${ }^{131}$ I is the treatment of choice for hyperthyroidism, if it could not be used, surgery or drugs would be required. Fatalities associated with these therapies would greatly exceed any theoretically predicted increase in thyroid cancer from ${ }^{131}$ I in the atmosphere. 
It should not be assumed that these kinds of costly ramifications would be confined only to a radionuclide rulemaking, but could be the unfortunate result of a bright line approach to air toxic rulemaking in general. As evidenced by a radionuclide rulemaking based on $10^{-4}$, the desired goal of achieving. lasting health benefits could, in fact, be undermined by a rigid approach that debilitates the effort.

Further, the Administration was advised by many facilities currently regulated by the NRC, including research and testing reactors, medical facilities, and the National Institutes of Health, that regulatory schemes that involve unnecessary duplication of compliance and implementation needlessly raise costs and divert resources from needed research and other activities: This could adversely affect patient care at some facilities. DOE shares our concern over the dual regulations and absolute risk standards and their potential impacts on nuclear énergy, commercial, and research industries. Therefore, we believe that the pending revisions to the clean Air Act should contain a provision to eliminate unnecessary and duplicative authority to regulate radionuclide emissions from NRC-licensed facilities. To be consistent, DOE believes the language will be needed as an amendment to the Atomic Energy Act to require that additional facilities, not licensed by the NRC (e.g. DOE reactors and non-reactor nuclear facilities), meet NRC regulations on radionuclides emissions.

Honorable William G. Rosenberg

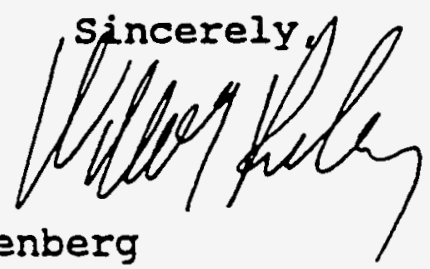

Assistant Administrator

for Air and Radiation

Environmental Protection Agency

James O. Mason, MD, Dr. P.H. Assistant Secretary for Health and Acting Surgeon General Department of Health and Human Services

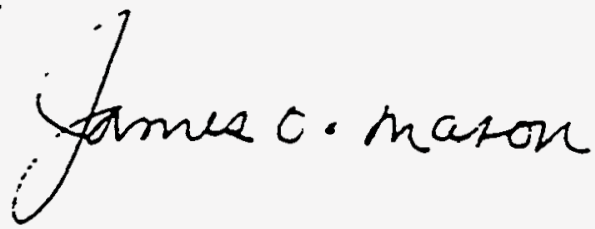

